Z. Dt. Ges. Geowiss. (J. Appl. Reg. Geol.), 172 (3), p. 227-249, 14 figs.

\title{
Early Carboniferous limestones of southern and central Britain: Characterisation and preliminary assessment of deep geothermal prospectivity
}

\author{
Tim Pharaoh1', Darren Jones², Tim Kearsey², Andrew Newell ${ }^{3}$, Corinna Abesser ${ }^{3}$, \\ Tom Randles ${ }^{2}$, Ashley Patton ${ }^{4} \&$ Rhian Kendall ${ }^{4 *}$
}

Pharaoh, T., Jones, D., Kearsey, T., Newell, A., Abesser, C., Randles, T., Patton, A. \& Kendall, R. (2021): Early Carboniferous limestones of southern and central Britain: Characterisation and preliminary assessment of deep geothermal prospectivity. - Z. Dt. Ges. Geowiss., 172: 227-249, Stuttgart.

\begin{abstract}
In Britain, thick limestones of early Carboniferous (Mississippian: 359-323 Ma) age are present in two provinces, respectively south and north of the Wales-Anglo-Brabant landmass. In the southern province, early Carboniferous limestones were deposited upon a southward-deepening shelf, laterally continuous from Ireland to the Rhineland. They now occupy a number of discrete minibasins as a consequence of Variscan orogenic thrusting and significant post-Carboniferous erosion. In the northern province, local tectonic controls led to the development of a mosaic of deepwater basins, ramps and platforms in response to Mississippian extensional stress. The interaction with glacioeustatic sea-level change led to the development of complex carbonate system tracts on these ramps and platforms.

Given favourable conditions of palaeokarst development and fracturing, hydraulic transmissivity could be sufficient to allow development as a geothermal resource. Deep geothermal prospectivity is controlled by a hierarchy of factors, operating on scales ranging from provincial (1000-100 km) down to outcrop (1000-100 m), reflecting processes operating on the lithospheric down to sub-basinal scale respectively. On the scale of the individual prospect, these factors include the mode of carbonate deposition, particularly depth of water and angle of depositional slope, which are tectonically controlled; the history of synsedimentary exposure, erosion and karstification, strongly influenced by sea-level change; by the diagenetic history and subsequent basin evolution; by deformation and fracturing during Variscan basin inversion; and by the postCarboniferous history of subsidence, uplift and karstification.

The contrasting impact of these various processes upon hydraulic transmissivity in the two provinces is reviewed, and a preliminary assessment of the geothermal prospectivity of each is presented. The most prospective areas for deep geothermal exploitation are considered to be basins, shelves and platforms lying at depths of 2 to $5 \mathrm{~km}$ below sea level. Deepwater basins are considered less prospective because of the lack of thick limestones, except in the hanging wall at fault-bounded margins, where Waulsortian mud-mounds with good residual porosity and fault-zones with polyphase history are likely present. Granite underpinned highs in N England, where Carboniferous limestones are typically at crop, and shallow basins of Carboniferous age lying on the Wales-Anglo-Brabant Massif, are considered less prospective in the deep geothermal context.
\end{abstract}

Keywords: Mississippian, limestone, Britain, palaeokarst, fracturing, deep geothermal prospectivity

\section{Introduction}

Early Carboniferous limestone (ECL) of Mississippian age is present in the subsurface over large areas of southern and central Britain and was identified as a promising deep geothermal play by Doug Holliday (1986), alongside other low enthalpy deep geothermal resources such as Permo-Triassic clastic-filled sedimentary basins. The latter were investi- gated during the first round of research on the low enthalpy resource in the 1980's, resulting in only one development, at Southampton (Fig. 1), which has been contributing to an urban district heating scheme since the early 1980's. No further investigation of ECL has been carried out, despite successful exploration and exploitation of the resource elsewhere, e.g. in Belgium (Delmer et al. 1996; Bos \& Laenen 2017) and The Netherlands (Reijmer et al. 2017; Mijnlieff

\footnotetext{
*Addresses of the authors:

${ }^{1}$ British Geological Survey, Environmental Science Centre, Keyworth, Nottinghamshire, NG12 5GG, UK (tcp@bgs.ac.uk)

${ }^{2}$ British Geological Survey, The Lyell Centre, Research Avenue South, Edinburgh, EH14 4AP, UK

(darjones@bgs.ac.uk / timk1@bgs.ac.uk / tar@bgs.ac.uk )

${ }^{3}$ British Geological Survey, Maclean Building, Wallingford, Oxfordshire, OX10 8BB, UK (ajn@bgs.ac.uk / cabe@bgs.ac.uk)

${ }^{4}$ British Geological Survey, Cardiff University, Park Place, Cardiff, CF10 3AT, UK (ashleyp@bgs.ac.uk / rhnd1@bgs.ac.uk)
} 
2020). In the context of this paper, 'deep geothermal' is defined as lying within the depth range of 500-5000 m below ground surface. Low enthalpy resources shallower than this, e.g. water from flooded mines, may be exploited using ground source heat pumps, but are not assessed here; neither are high enthalpy systems, at deeper levels.

The ECL can be a productive aquifer (Abesser et al. 2005; Abesser \& Smedley 2008; Narayan 2019; Narayan et al. 2021), hosting deep hydrothermal circulation systems which source thermal waters at Bath, Bristol, the Taff Valley and Buxton (Darling 2019) (Fig. 1). With an estimated contained accessible subsurface resource of up to $328 \times 10^{18}$ Joules (Busby 2014), this direct-use geothermal heat could make a significant contribution to the decarbonisation of heating (Atkins 2013). Although less predictable than other deep geothermal resources, ECL has the advantage that it occurs at depths in the range 500-4000 m beneath many UK conurbations, and hence could supply significant energy to urban district heating schemes. Successful exploitation of geothermal aquifers generally requires good effective porosity (>20\%), permeability ( $>0.5-1 \mathrm{D})$, and thickness $(>20 \mathrm{~m})$, preferably overlain by an insulating unit ('thermal blanket') with low thermal conductivity (Holliday 1986), e.g. mudstone. Flow rates of 50 to $100 \mathrm{~m}^{3} / \mathrm{h}$ are required in each well (Rockel et al. 1997). In contrast, ECL generally has significantly lower porosity $(<1-1.3 \%)$, lower permeability $(1-10 \mathrm{mD})$ and insignificant intergranular flow (Downing \& Gray 1986; Abesser et al. 2005) but given favourable circumstances, transmissivity could be significantly higher (Narayan et al. 2018, 2021). Market considerations are also a significant factor in development. The aquifer temperature should be $>100{ }^{\circ} \mathrm{C}$ for power generation; $>50^{\circ} \mathrm{C}$ for heat production; and $>20^{\circ} \mathrm{C}$ for balneological and horticultural applications.

Groundwater flow in ECL is controlled by the development of secondary permeability, e.g. associated with faulting, karstification, dissolution of evaporites or dolomitisation (Juerges et al. 2016; Narayan et al. 2018, 2021). The key to successful exploitation of the ECL resource is the presence of aquifers in which hydraulic transmissivity has been significantly enhanced by the interaction of these various phenomena, as has been demonstrated at Saint Ghislain and Mol in Belgium, and near Venlo in The Netherlands (Berckmans \& Vandenberghe 1998; Dusar \& Lagrou 2008; Bos \& Laenen 2017; Reijmer et al. 2017; Van der Voet et al. 2018; Broothaers et al. 2021, this issue). To date, the only drilling of ECL in Britain has been to address the contribution from a high heat production granite underlying the Alston Block (Manning et al. 2007). A further borehole at Science Central, University of Newcastle-Upon-Tyne, tested clastic strata of Mississippian age and fault prospectivity, but not ECL facies. The Southampton geothermal borehole, mentioned above, exploits water from the Sherwood Sandstone Group (Triassic), not the Old Red Sandstone (Devonian) clastic facies reached at terminal depth (TD). The latter strata have very low porosity $(<3 \%)$ and average permeability $(<0.2 \mathrm{mD})$ (Burgess et al. 1981).

This paper reports preliminary findings on geothermal prospectivity of the ECL, from a study using sub-surface mapping and play fairway analysis, currently being undertaken by BGS (Jones et al. 2021). Basins in Scotland and northern England containing 'Yoredale' facies of Mississippian age are dominated by clastic strata and contain thin, if any, limestones. For example, the Seal Sands Borehole (Fig. 1) in the Stainmore Basin, penetrated 3442 m of Mississippian strata containing only two limestones thicker than $30 \mathrm{~m}$ (Chadwick et al. 1995). These strata are not part of the Carboniferous Limestone Supergroup, and, like the unprospective pre-Carboniferous rocks underlying the WalesAnglo-Brabant Massif (WABM), are specifically excluded from this study.

\section{Mississippian palaeogeography}

In early Carboniferous (Mississippian: 359-323 Ma) time, Britain lay at equatorial latitudes and carbonate sediment accumulated in warm shallow shelf seas surrounding the WABM, a persistent late Palaeozoic palaeogeographic feature (Pharaoh 2018), stretching from Wales to Belgium (Fig. 2). The southern arm of this sea formed part of the Rhenohercynian Shelf lying to north of the Rheic Ocean, and subsequently the incipient Variscan Orogen. Thin transgressive sequence tracts preceding maximum flooding surfaces (MFS) on the WABM may have been eroded subsequently. Numerous and widespread palaeokarst and palaeosol horizons in the adjacent marine platforms testify to intermittent uplift and erosion (Walkden 1987; Wright 1990). In addition to local tectonism, these basins were affected by glacioeustatic changes in sea level, as the planet gradually moved towards Icehouse conditions (Davies \& Fielding 2008). Limestones deposited during this period are associated with platforms, ramps and shelf-slope areas. Clastic sedimentary rocks dominate deeper-water shelf or turbiditic successions.

NW Europe was part of a tectonically active equatorial seaway which subsequently became filled by a clastic deltaic river system, predominantly from the north (Waters \& Davies 2006; Kombrink et al. 2010; Kearsey et al. 2019). The interplay of sedimentation and local tectonics created a very variable set of depositional environments (Fig. 2), with different types of basin-fill, subsidence rate and inversion structures developing to the south and north of the WABM (Figs. 1, 2). These two provinces are referred to subsequently in the text as the southern and northern ECL provinces. The major Mississippian stratigraphic units, and their correlation with the strata of the NW European basins, are shown in Fig. 3.

\section{Depositional settings}

\section{Carbonate platform facies}

Carbonate successions are developed on platforms and shelves across England (Davies \& Fielding 2008). These are most substantial fringing the WABM and around the Market Weighton High (Figs. 1, 2). For instance, in the Grove 3 Borehole there is a virtually continuous $1200 \mathrm{~m}$ thick section of carbonate strata. However, in the numerous microbasins 


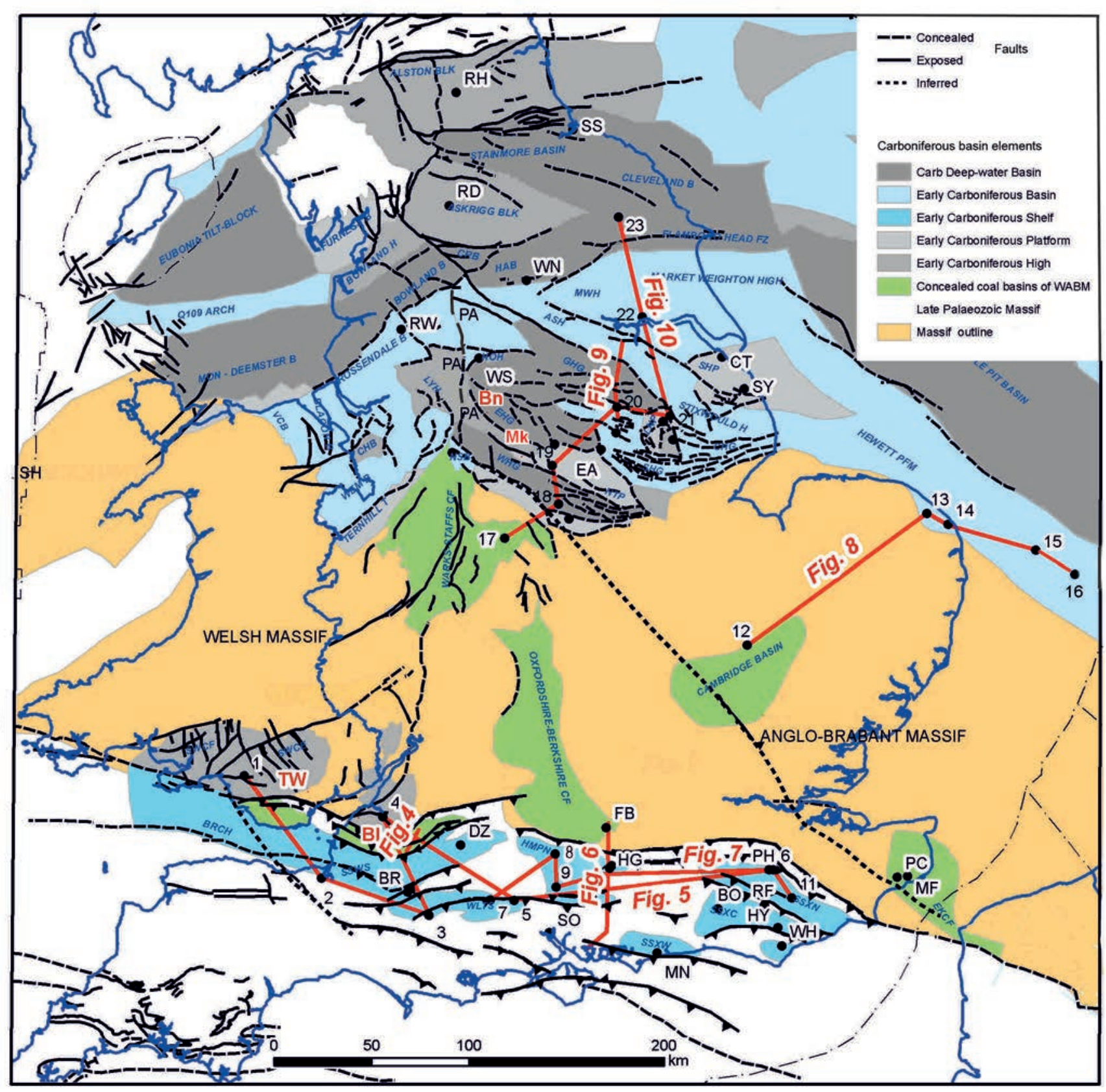

Fig. 1: Map of ECL subcrop in southern and central Britain. The location of sections in later diagrams is shown in red. Key to ECL basin abbreviations: ASH - Askern-Spital High; BRCH - Bristol Channel; EHG - Edale Half-graben; EKCF - East Kent Coalfield; FDCF Forest of Dean Coalfield; GHG - Gainsborough Half-graben; HMPC - Central Hampshire subcrop; HMPN - North Hampshire subcrop; MWH - Market Weighton High; SHP - South Humber Platform; SNG - North Somerset \& Gloucestershire subcrop; SSC - Central Somerset subcrop; SSWS - South Somerset \& North Wiltshire subcrop; SSXC - Central Sussex subcrop; SSXN - North Sussex subcrop; SSXS - South Sussex subcrop; SSXW - West Sussex subcrop; ST - Stainmore Trough; SWCE - South Wales Coalfield East; SWCS - South Wales Coalfield South; SWCW - South Wales Coalfield West; WHG - Widmerpool Half-graben; WLTS - South Wiltshire. Key to boreholes in well transect diagrams, linked by red lines: 1 - Maesteg 1; 2 - Knap Farm (Cannington Park); 3 - Fifehead Magdalen 1; 4 Ashton Park; 5 - Farley South 1; 6 - Ashour 1;7 - Netherhampton 1; 8 - Egbury 1; 9 - Stockbridge 1; 10 - Herriard 1; 11 - Wallcrouch 11; 12 - Cambridge; 13 - East Ruston 1; 14 - Somerton 1; 15 - 53/12-2; 16 - 53/18-1; 17 - Alrewas 1; 18 - Long Eaton 1;19 - Ironville 5; 20 - Grove 3; 21 - Welton 1; 22 - Broomfleet 1; 23 - Kirby Misperton 1. Key to other boreholes and locations mentioned in the text: BO Bolney 1; BR - Bruton; CT - Cleethorpes 1; DZ - Devizes 1; EA - Eakring 146; EG - Egmanton 68; FB - Foudry Bridge 1; FW - Farleigh Wallop 1; HA - Hathern 1; HC - Hester's Copse 1; HD - Herriard 1, HG - Humbly Grove X1; HT - Hardstoft 1; HY - Hellingly 2; IC Inwood Copse; MF - Meggot Farm; MG - Milton Green 1; MN - Middleton 1; NF - Nooks Farm 1; NM - Nettleham 2; PC - Paddleworth Court; PH - Penshurst 1; RD - Raydale; RH - Rookhope; RW - Roddlesworth 1;RO - Rotherfield; SO - Southampton 1; SY - Saltfleetby 1; SS - Seal Sands 1; WH - Westham 1; WM - Warlingham; WN - Weeton 1; WS - Wessenden 1. Key to thermal springs: Bl - Bristol-Bath area; Bn - Buxton; Mk - Matlock; TW - Taff's Well. 


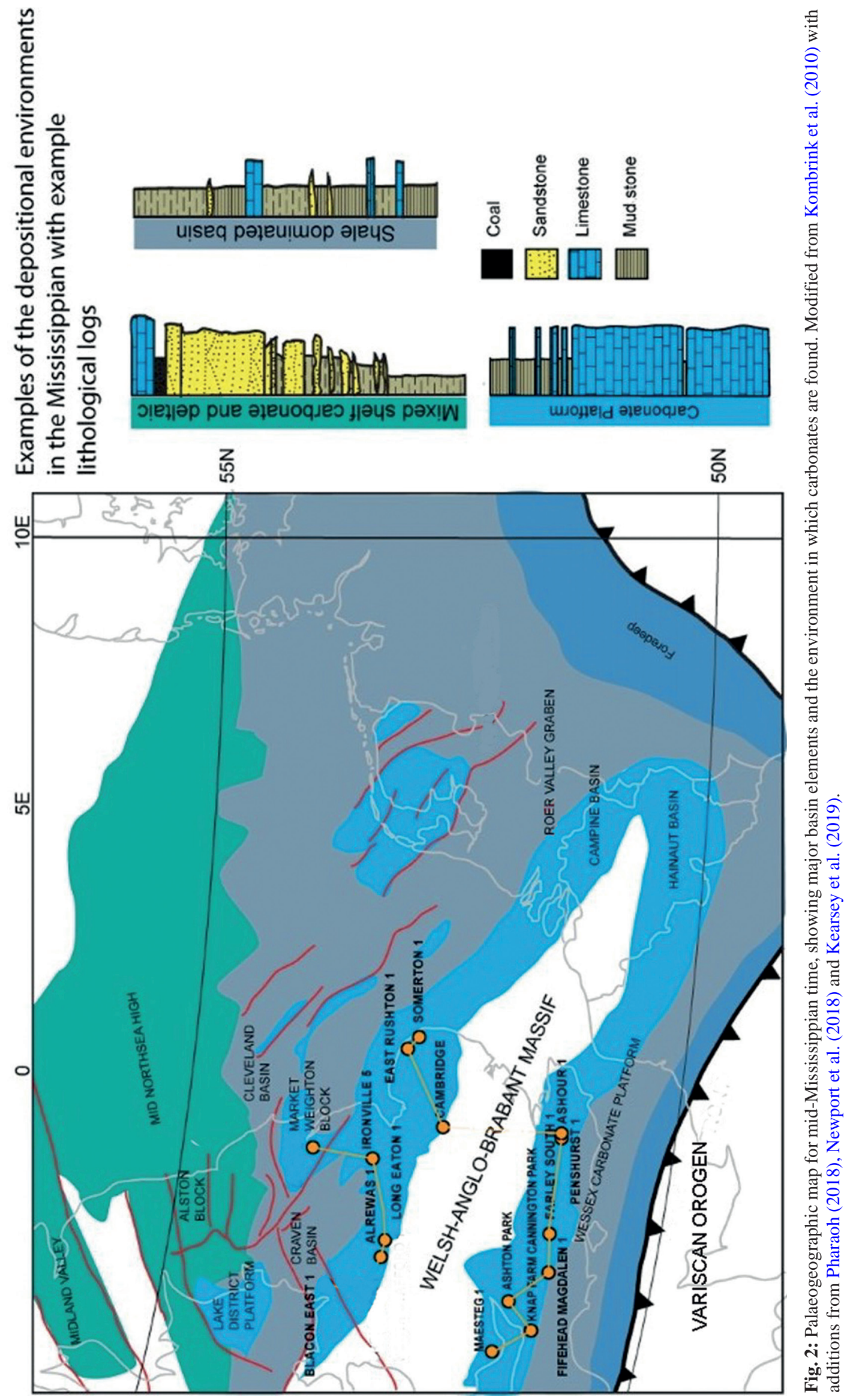


on the northern edge of the WABM there is very close juxtaposition between carbonate platforms and clastic basinal sediments. To the south of the WABM the carbonates are thinner, but part of an originally more continuous shelf. These have been shown to have different morphotectonic settings; inner, mid-and outer parts of a southward-dipping shelf ramp complex (Wright 1986).

\section{Shale dominated basin facies}

In the basin areas, such as the Bowland and Cleveland basins, the sediment is dominated by mudstones and thin sandstone beds (Fig. 2). However, even in these basinal environments carbonates are present in up to $10 \mathrm{~m}$ thick beds. These are thought to be carbonate turbidity and slope deposits which carried material from the platform into the basin areas (Newport et al. 2018; Waters et al. 2020, Narayan et al. 2021).

\section{Mixed shelf carbonate and deltaic facies}

In Northumberland, the Midland Valley of Scotland and the North Sea, most carbonate is associated with the 'Yoredale Facies' (Tucker et al. 2003; Kearsey et al. 2019). The limestones in these successions tend to be 1-5 m thick, interbedded in an upward-coarsening succession of marine mudstone and sandstone, and capped by a coal layer (Fig. 2; Kearsey et al. 2019, Booth et al. 2020). These limestones are formed by marine transgressions in response to glacio-eustatic sea-level changes (Davies \& Fielding 2008).

\section{Southern ECL province}

The Carboniferous Limestone Supergroup (Mississippian) was deposited in carbonate ramp environments, forming part of a marine shelf extending from Ireland to the Rhineland (Bless et al. 1976), subsequently tectonically incorporated within the 'Rhenohercynian' or 'Externide Zone' of the Variscan Orogen. The supergroup crops out around the margins of the South Wales Coalfield, Forest of Dean Coalfield, Bristol-Somerset Coalfield and in the Mendip Hills. This region is notable for the development of thermal springs (Fig. 1) formed in association with deep groundwater pathways through the ECL underlying synclinal coalfield basins, of which the thermal aquifer at Bath is perhaps the best example, known since Roman times.

Outcrop in the Avon Gorge-Mendip region (Fig. 3) comprises up to $1000 \mathrm{~m}$ of limestone and dolomite assigned to the Avon and Pembroke Limestone groups (Waters et al. 2011). ECL were deposited in a ramp environment with water depths generally increasing to the south. Microbialite mud mounds ('Waulsortian Reef' facies) are known from distal slope facies (Berry Slade Formation) farther west in Pembrokeshire (Waters et al. 2011). The lower, mudstonerich Avon Group (formerly Lower Limestone Shales) of Tournaisian age, passes upwards into the Pembroke Limestone Group (Tournaisian-Visean).

The maximum preserved thickness of the latter is around $800 \mathrm{~m}$, but is highly dependent on the degree of post-Variscan erosion. The muted geophysical log response (Fig. 5) with generally low gamma-ray and sonic travel times belies lithological heterogeneity comprising oolitic limestone bodies, bioclastic limestones, muddy offshore bioclastic limestones, shales and chert, reef mounds, peritidal limestones and minor volcanic rocks.

The presence of palaeokarst in the limestones (Fig. 4) likely facilitates the passage of water to the Bath occurrence (Gallois 2007). Unfortunately, few of the existing 2D seismic reflection data, optimised to image the hydrocarbonprospective Mesozoic section, provide a clear image of the structure in the late Palaeozoic strata. However, it is very likely that they are involved in fold-thrust nappes, comparable to those of the Dinant Syncline of Belgium, close to the front of the Variscan Orogen (Fig. 2). Underlying strata of Old Red Sandstone facies, as proven by the Southampton and Marchwood boreholes, perhaps $2 \mathrm{~km}$ thick, have low porosity and permeability and are not considered prospective for deep geothermal exploitation (Downing \& Gray 1986).

Dolomitic limestone predominates toward the base of the group, while siliciclastic sandstones occur near the top. Sealevel lowstands at the end of Courceyan and early Chadian time, resulted in the development of several discordances marked by palaeokarstic horizons with palaeosols that can be correlated over large areas (Wright 1986; Faulkner et al. 1990), e.g. at the base and top of the Gully Oolite (Fig. 3). Supratidal sabkha-type algal microbialites are present in South Wales (Caswell Bay Mudstone Formation: Arundian) and in the Avon Gorge (Concretionary Beds Member: Holkerian) (Wright 1986; Kirkham 2005). These are comparable (in both lithology and age) to late Visean (Livian-Warnantian) evaporite-bearing sequences in Belgium (Muchez \& Peeters 1987), whose dissolution has given rise to the spectacular collapse breccia/olistostrome of regional extent known as the 'Grande Brèche' (Fig. 3).

East of the Mississippian crop, ECL dip beneath a thick Mesozoic cover, extending in a belt on the southern flank of the WABM, from Somerset to Sussex (Fig. 1). The seismic mapping here by Jones et al. (2021) took ECL subcrop limits provided by Pullan \& Butler (2019) as a starting point. The ECL is more restricted than represented in some earlier mappings (e.g. Smith 1985). ECL has been proven in a large number of oil exploration boreholes at depths of 800-2000 m below sea level, although most penetrate only a few metres. Fig. 5 shows the few boreholes with significant penetration and geophysical logs which facilitate well correlation. The maximum proven thickness is nearly $1000 \mathrm{~m}$ (Knap Farm, Cannington Park Borehole), comparable to the thickness at outcrop in the Mendip-Avon Gorge region. Many other boreholes fail these criteria, usually only penetrating a few metres of ECL, as this was regarded as the top of 'economic basement' during the drilling of exploration wells in the Mesozoic basins in the $20^{\text {th }}$ Century. Although the geophysical logs are sparse, the data available (Fig. 5) suggest comparable stratigraphic thickness and character across the southern province, as noted by Whittaker et al. (1985).

Little detailed biostratigraphical work has been done on any of these provings, and the following age attributions are those from the well composite logs. Westham 1 , Warlingham 


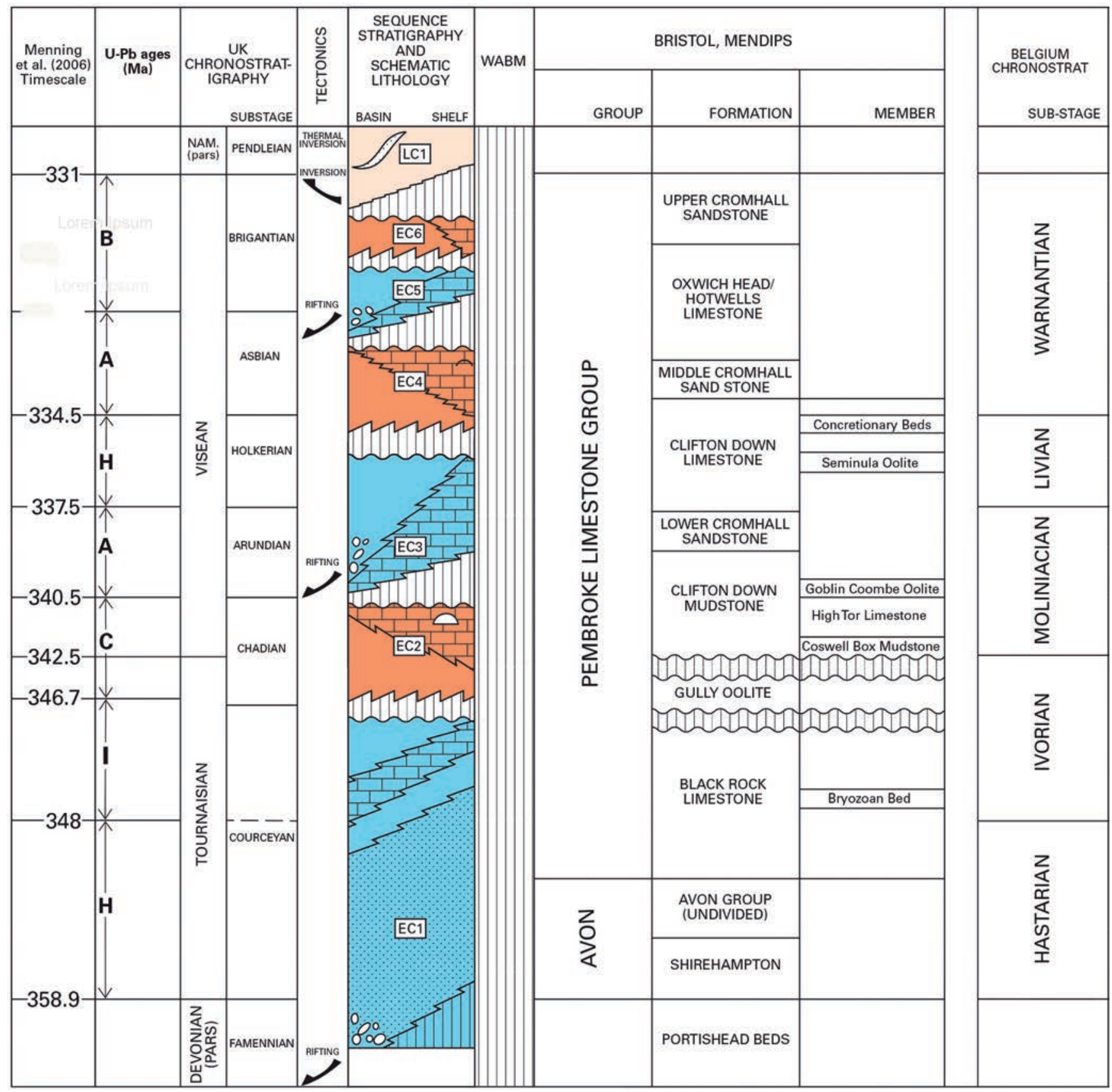

Fig. 3: Sequence stratigraphy for Mississippian strata in the NW European area: (a) Central and Southern Britain on either flank of the WABM (left hand side of diagram), with transgressive/regressive sequence tracts in blue and orange respectively. (b) Hainaut and Campine basins flanking the Brabant Massif (BM) in Belgium (right hand side of diagram). GB is the horizon of the Grande Brèche (Livian, V3a) in the Hainaut Basin. Compiled from Menning et al. (2006), Gradstein et al. (2012) and Cohen et al. (2012). Local stratigraphic schemes after Fraser \& Gawthorpe (1990), Kirkham (2005), Poty et al. (2006), Waters et al. (2011), Licour (2014), Rorive \& Licour (2014, 2015), Poty (2016) and Lagrou \& Laenen (2012, 2014).

and Fifehead Magdalen 1 (Courceyan), Humbly Grove X1 (1), A1 (2), B1 (3), Herriard 1, Hesters Copse 1, and possibly dolomitic limestones at Farley South 1, are all of likely Tournaisian age. Penshurst 1 (Arundian-Holkerian), Farleigh Wallop 1 and Rotherfield 1 (Holkerian?), Netherhampton 1 (Asbian) and Inwood Copse 1 are of Visean age. In general the degree of erosion increases southward into the orogen, although a notable reversal of this trend is at Middleton 1 (Fig. 1), where Coal Measures are presumed to overlie ECL. Watson et al. (2020) have reviewed the potential for repurposing some of the above wells and oilfields for geothermal use. 


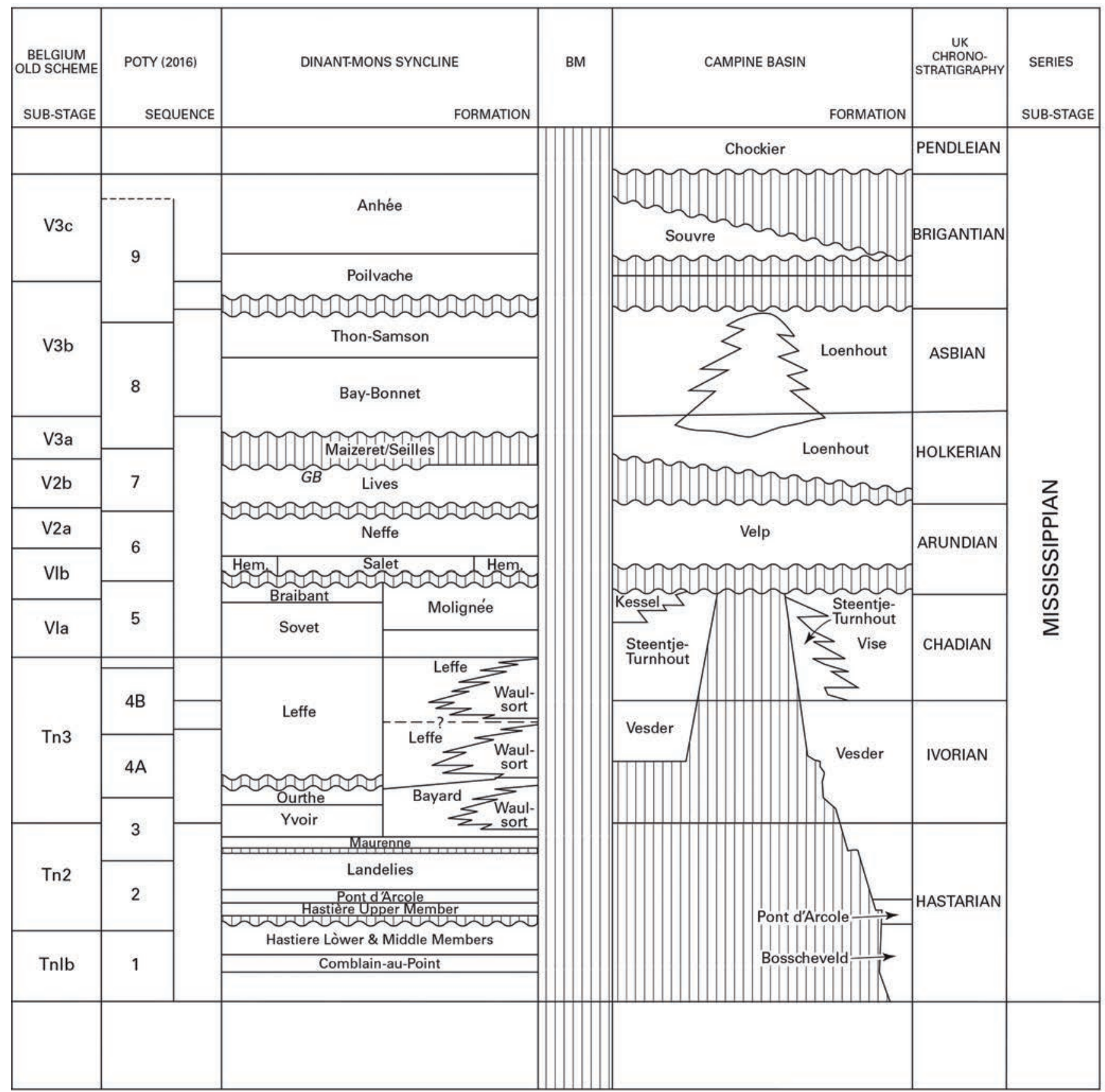

Fig. 3: cont.

Foudry Bridge Borehole (Fig. 1) within the concealed Berkshire Coalfield proved a very thin sequence of ECL immediately north of the Variscan Front. A further isolated subcrop of ECL underlies the East Kent Coalfield syncline (Fig. 1), which extends beneath the Dover Strait to the NordPas de Calais Coalfield of northern France (Laurent et al. 2021, this issue). In Kent, a relatively thin (c. $140 \mathrm{~m}$ ) sequence of ECL, including Tournaisian strata lies at a relatively shallow depth of about 400-600 m below sea level and are therefore a less valuable target for geothermal exploration. However, some coal exploration boreholes (e.g. Meggot
Farm Borehole) show that ECL of Holkerian age are separated from overlying Westphalian strata by a zone of karstification with fissures up to $1.4 \mathrm{~m}$ deep. This evidence may be valid for the province as a whole, where Pennsylvanian and late Mississippian strata have largely been removed by postVariscan erosion.

Seismic interpretation suggests that the ECL occupies the footwall synclines of a series of thrust sheets (Fig. 1), each truncated by the overlying klippen. Although the seismic image is rarely clear, structural dips appear to be mostly low, although dips of up to $75^{\circ}$ were observed in core from Bol- 
Temperature

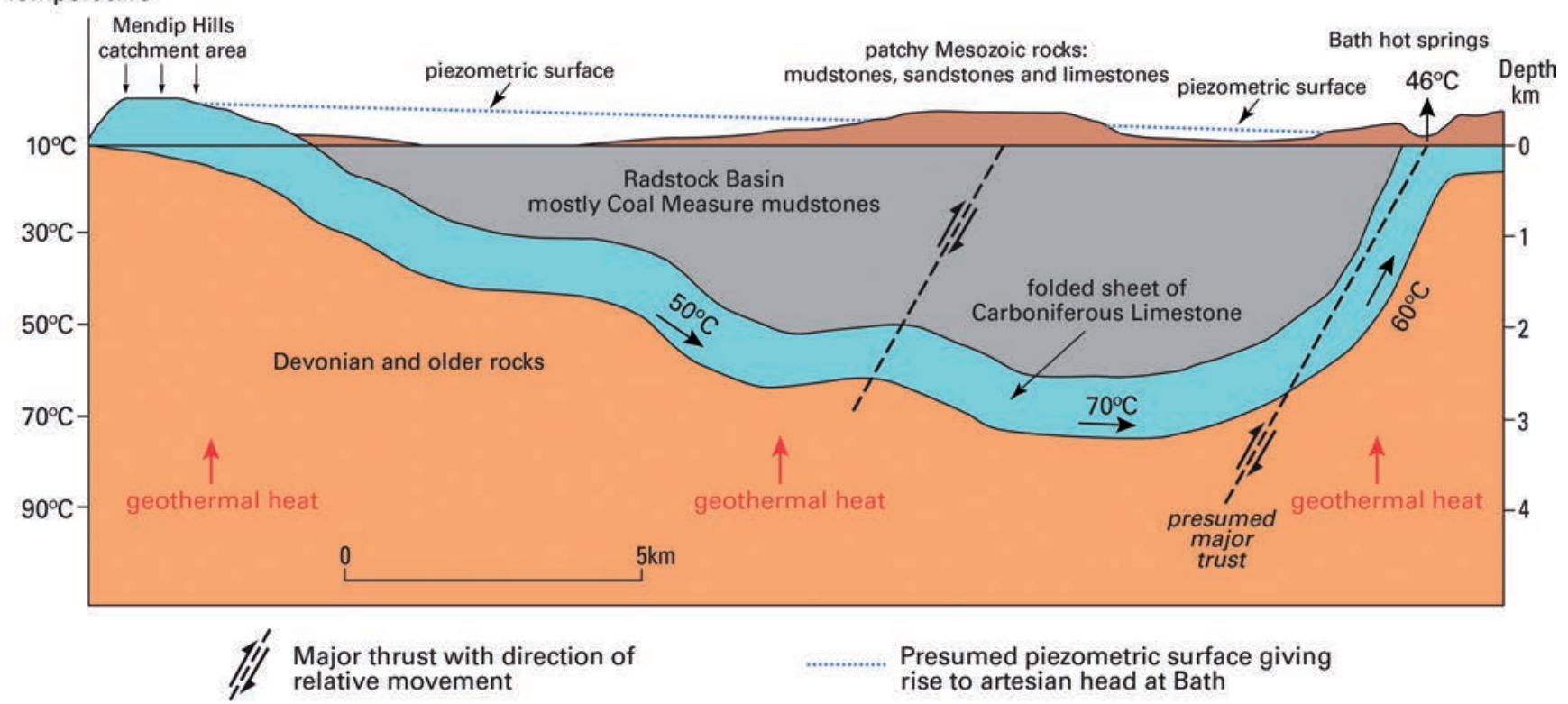

Fig. 4: Schematic cross-section across the Mendip-Bath thermal aquifer. Modified from Edmunds (1986) and Gallois (2007). Vertical exaggeration x2.
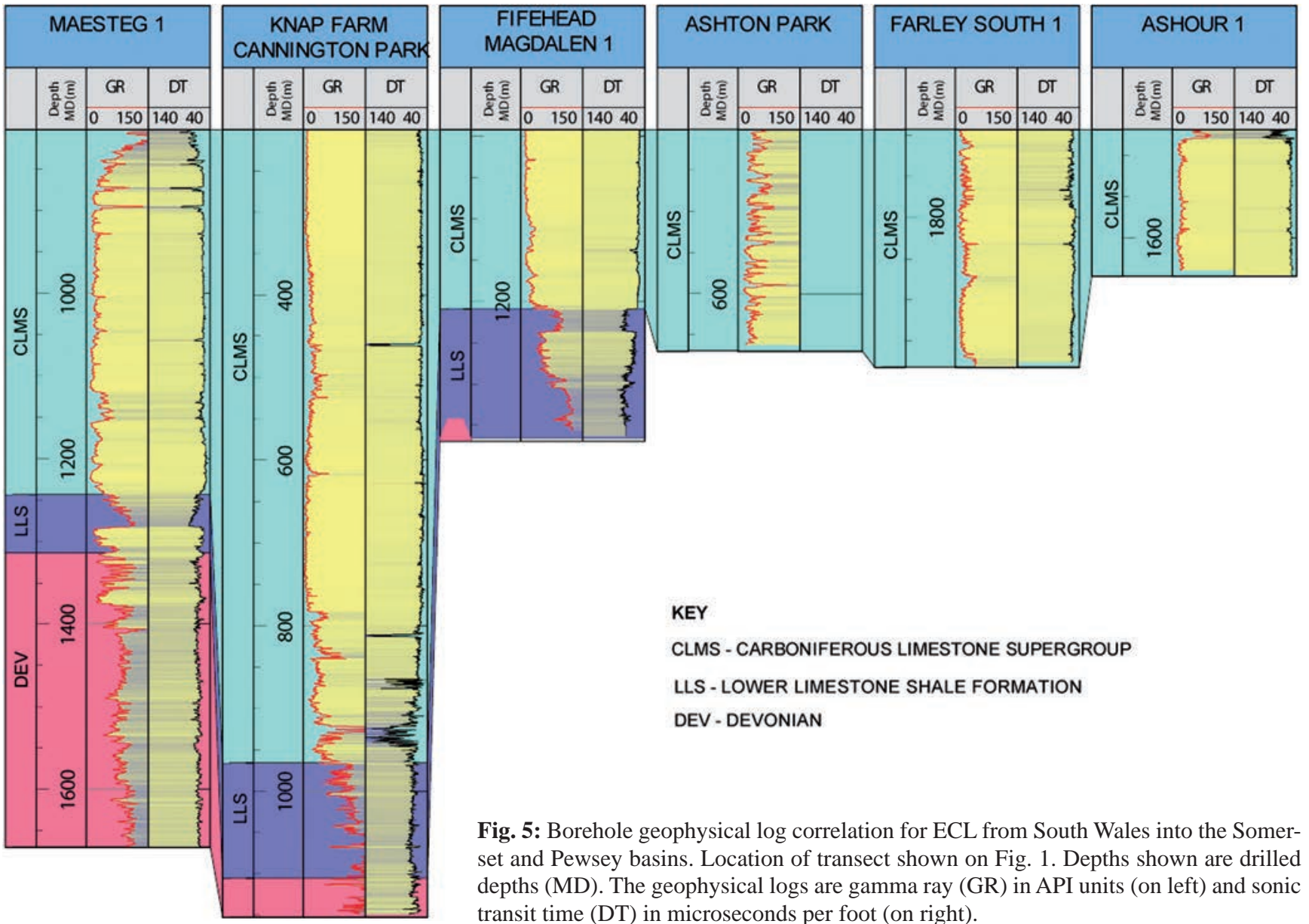

KEY

CLMS - CARBONIFEROUS LIMESTONE SUPERGROUP

LLS - LOWER LIMESTONE SHALE FORMATION DEV - DEVONIAN

Fig. 5: Borehole geophysical log correlation for ECL from South Wales into the Somerset and Pewsey basins. Location of transect shown on Fig. 1. Depths shown are drilled depths (MD). The geophysical logs are gamma ray (GR) in API units (on left) and sonic transit time (DT) in microseconds per foot (on right). 


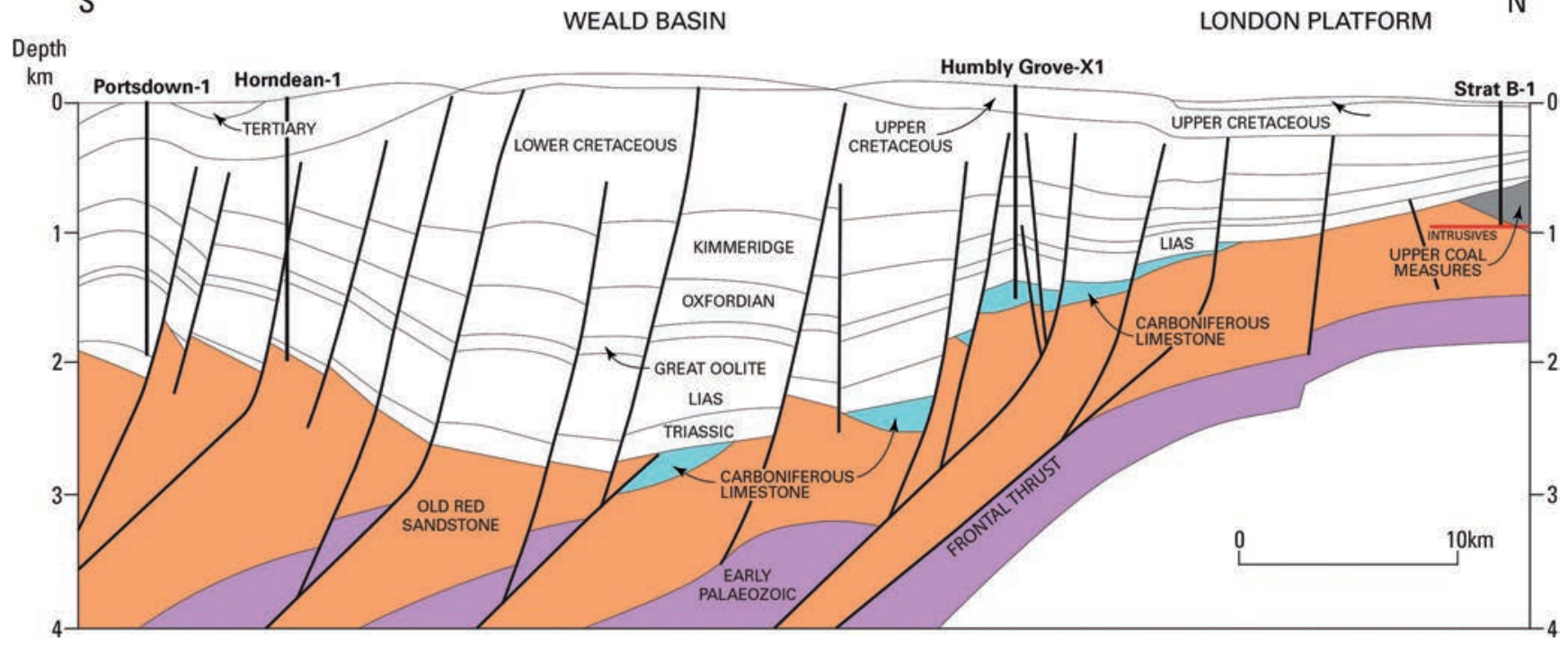

Fig. 6: Schematic S-N cross-section across the western part of the Weald Basin. Mesozoic stratigraphy following Gluyas et al. (2020). The Variscan structure is schematically shown. Vertical exaggeration x8. Location shown on Fig. 1.

ney 1 Borehole (Fig. 1), where an asymmetrical fold/thrust may be present (Composite Log). The boreholes which prove ECL are clustered around the Mesozoic Pewsey and Weald basins, in both the footwall highs to the north of the major W-E controlling normal faults (Fig. 6) and on the inclined flanks of the major hanging-wall depocentres.

The ECL subcrop in a series of minibasins is a complex function of the original shelf depositional pattern, northdirected Variscan thrusting and folding, a prolonged phase of late Carboniferous to Triassic subaerial erosion, and subsequent normal faulting and development of the extensional basins. Both at outcrop and in the subsurface, the ECL has a complex onlap relationship with Permo-Triassic and early Jurassic strata where these are superimposed across the Variscan Unconformity, on both local and regional scales (Figs. 6, 7). The Mercia Mudstone Group (Triassic) shows large thickness variations reflecting both the progressive infill of post-Variscan topography and the development of extensional fault-bounded basins and highs. Marine transgression (and in particular the mixing of marine- and fresh-water) in latest Triassic/earliest Jurassic time (Lovegrove et al. 2021) is known to have been an important factor in the development of palaeokarstic systems in topographic massifs of ECL prior to their total burial in early Jurassic time.

\section{Northern ECL province}

In the Midlands and northern England, the depth of ECL ranges from surface outcrop to $5500 \mathrm{~m}$ below sea level. The outcrops of ECL in North Wales, the Peak District of Derbyshire, the central Pennines of Yorkshire, the Dales of West Yorkshire, and the northern Pennines of Cumbria, Durham and Northumberland, comprise some of Britain's most dramatic landscapes. They provide analogues for lithological and structural features that control geothermal prospectivity at depth, such as palaeokarstification and emergence surfaces, stylolite development, fracturing, faulting and mineralisation. The areas of ECL outcrop also experienced significant karst development during Quaternary time, as well as in the preceding Cenozoic period (Walsh et al. 2018). However, they lie too shallow for deep geothermal exploitation (as defined above), as well as being remote from potential markets, and will not be further considered here. In addition to mapping published in various Subsurface Memoirs of the British Geological Survey, mapping for the Carboniferous Bowland Shale gas study (Andrews 2013) has been used as a proxy for Top ECL, particularly in East Yorkshire.

Areas where platformal ECL are buried at greater depths ( $>500 \mathrm{~m}$ ) are more prospective, and in many cases underlie urban conurbations, i.e. areas with high heat demand. These situations could include burial beneath thick Permian-Mesozoic sequences, as in the Cheshire Basin, and the flanks of the East Irish Sea and Southern North Sea basins; or beneath thick later Carboniferous strata, as in the Stoke-on-Trent area.

The margins of several basins rim the northern edge of the WABM. These include the Stafford, Needwood and Knowle basins in the west; and the Hathern Shelf, marginal to the East Midlands basin complex, in the east (Fig. 1). No systematic remapping of these marginal basins has been carried out. However, because their location coincides with the maximum thickness of Coal Measures in the 'bull's eye' of maximum thermal subsidence (Fraser \& Gawthorpe 1990), there may be places where ECL are buried deeply enough to be of interest e.g. in the Etruria Valley, where Stoke-on-Trent city council aspire to geothermal input to their nascent district heating network (http://www.gtenergy.net/projects/projects/etruria-valley-stoke-on-trent/the-project). The geophysical logs presented in Fig. 8 are representative of ECL sequences in these 


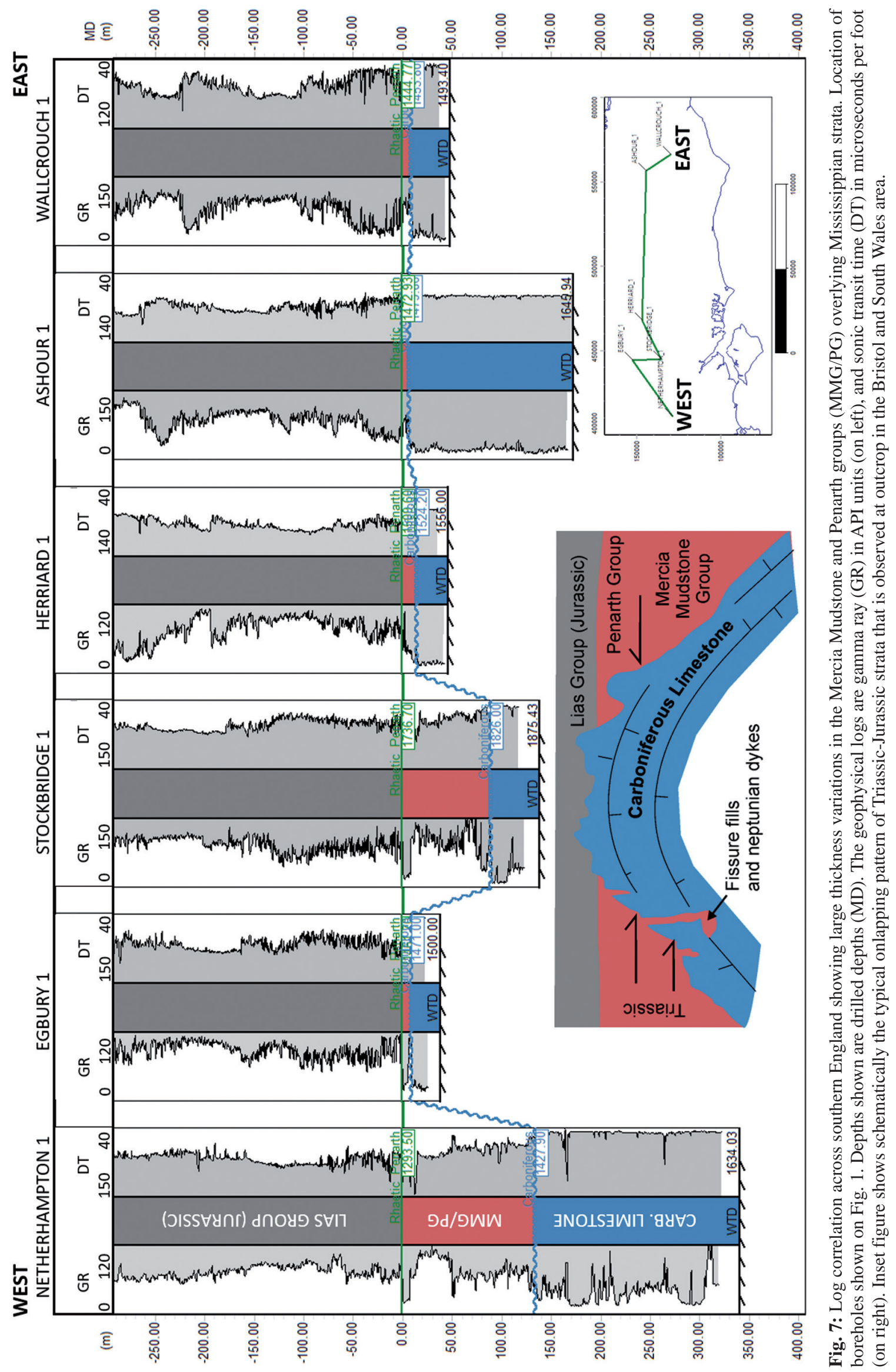




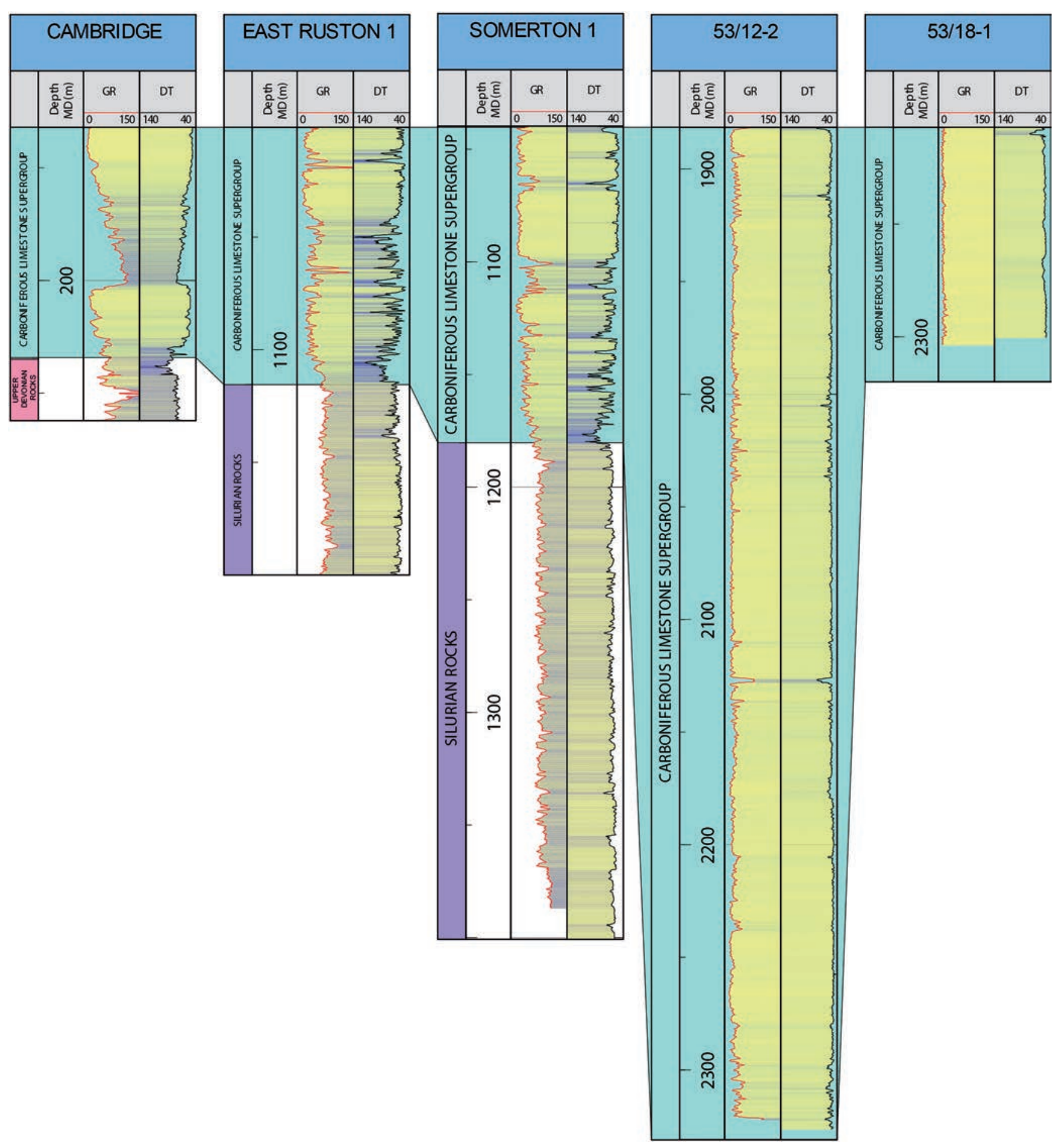

Fig. 8: Borehole transect for ECL across the NE edge of the WABM, towards the southern North Sea. Location of transect shown on Fig 1. Depths shown are drilled depths (MD). The geophysical logs are gamma ray (GR) in API units (on left), and sonic transit time (DT) in microseconds per foot (on right). 
basins marginal to the WABM. The offshore Hewett Platform, which extends across the southern North Sea towards The Netherlands, also finds a minor expression onshore on the coast of North Norfolk (Fig. 1). The thin and shallow sequence of ECL in the Cambridge Basin (Fig. 1) is clearly not of interest in the present context. In North Norfolk, the northern edge of the WABM likely experienced persistent uplift and emergence during Carboniferous time (Pharaoh et al. 2011), as well as the development of a sub-Cretaceous weathering profile. The latter has played a significant part in the development of palaeokarst in southern Belgium, south of the WABM (Dusar \& Lagrou 2008; Reijmer et al. 2017). The onshore/offshore transition across the Hewett Platform represented by the boreholes in Fig. 8, may have some potential, although once again, a market is presently lacking.

In the northern province, the Mississippian basins exhibit two principal structural styles. In the south (East Midlands region), the style and geometry of the basins is controlled by the structural grain and composition of the underlying Caledonide basement. Reactivation of basement thrust structures in response to early Carboniferous extension led to the formation of a mosaic of lozenge-shaped basins (Fig. 1) in Mississippian time, and their subsequent inversion in later Carboniferous time in response to Variscan orogenic compression (Pharaoh et al. 2011). Most of the basins are half-graben structures, with tilt-block geometry which significantly influenced the nature of carbonate deposition. In this region, Mississippian strata are largely concealed beneath a cover of Westphalian Coal Measures, or Permo-Triassic strata. In the north (Northern Pennine region), the style and geometry is different, as a consequence of the presence of large batho- liths of granite emplaced late in the Caledonian Orogeny. These had the effect of annealing earlier fault fabrics within the basement, as well as buoyantly supporting the resulting crustal blocks (Bott 1967, 1987). As a consequence, the latter formed highs e.g. the Lake District, Weardale and Cheviot blocks during Mississippian extension and deposition (Kirby et al. 2000), separated by rather linear basins e.g. the Bowland Basin and Stainmore Trough (Fig. 1). The graniteunderpinned blocks remain buoyant crustal features to this day, reflected in a thin Permo-Triassic cover and the presentday landscape, with Mississippian strata outcropping across the northern Pennines.

Throughout the province, platformal areas are juxtaposed with deep basins of the same age, in which carbonate facies may be partially or completely replaced by less prospective argillaceous or clastic facies (Fraser \& Gawthorpe 1990; Smith et al. 1995; Van Hulten 2012). The Gainsborough, Edale and Widmerpool half-grabens are deep water basinal structures largely concealed by Permian and younger strata (Pharaoh et al. 2011). A generalised cross-section across the Gainsborough Half-graben is presented in Fig. 9 and shows the typical features of such basins. The lateral distribution of carbonates on the basin edge is complicated, with 'reefs' feeding carbonate debris to low energy debris-flows nearer the basin centre (Newport et al. 2018). Carbonate ramps build up on the footwall dip-slope, and exhibit a complex structure (Fig. 3) as a result of transgressive and regressive cycles reflecting glacioeustatic sea-level change on a partially glaciated planet (Davies \& Fielding 2008). Fraser \& Gawthorpe (1990) recognise three transgressive systems tracts, developed following pulses of extension in Famenn-

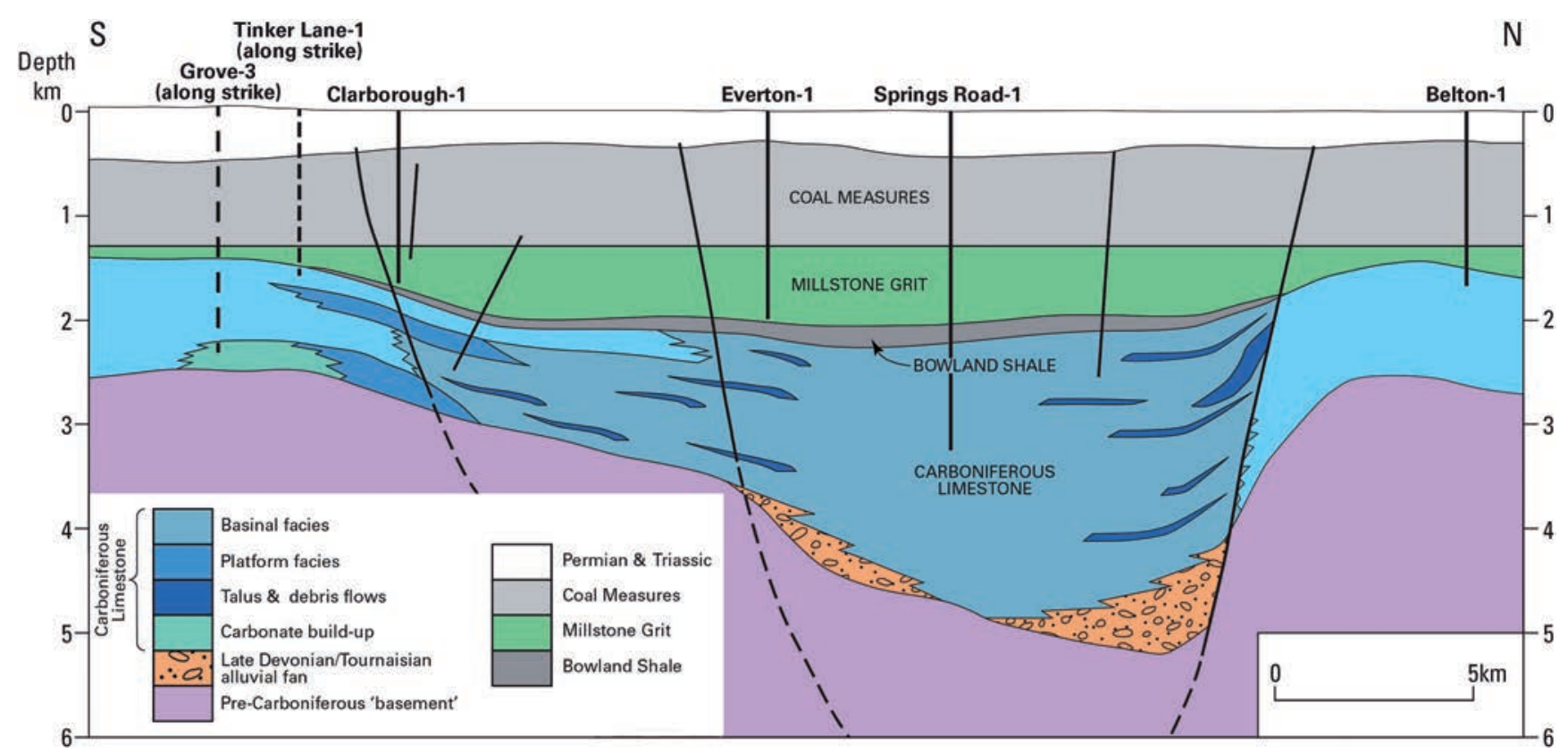

Fig. 9: Generalised S-N cross-section across the Gainsborough Trough. Modified from a depth converted seismic profile (IGas Energy plc 2019). Vertical exaggeration $x$ 2.5. The boreholes Grove 3 and Tinker Lane 1 lie slightly off the line of section ( $<1 \mathrm{~km})$. Location of crosssection is shown on Figs. 1 and 11. 

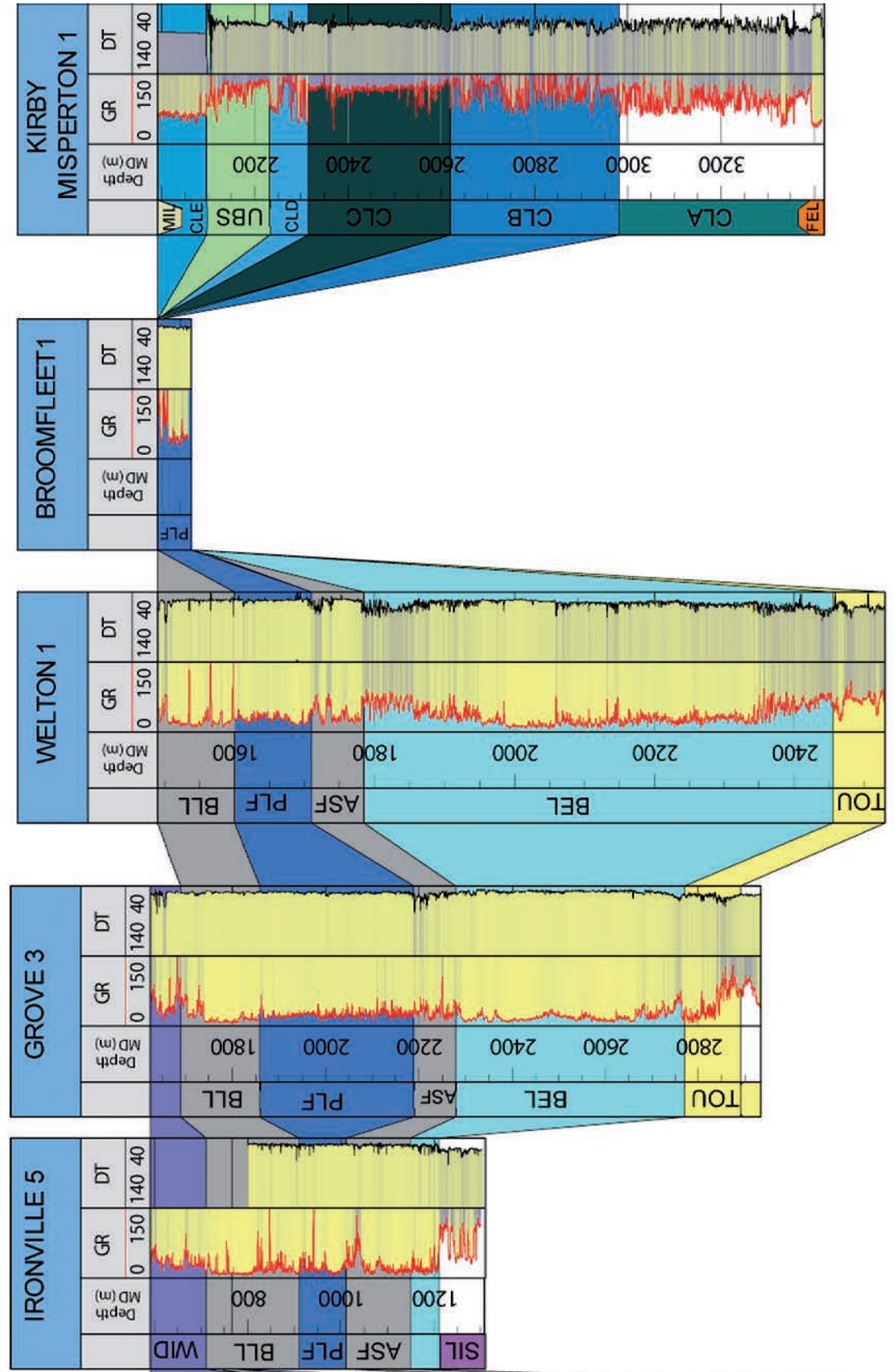

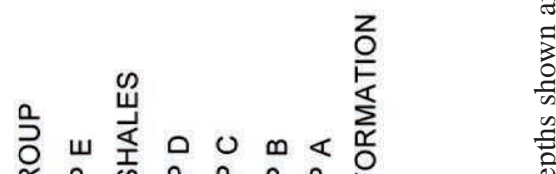

$\stackrel{\Xi}{E}$

品号号号号号

을 응일

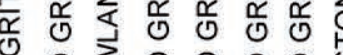

을을 은

员

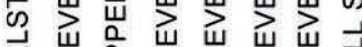

झ

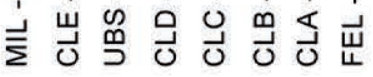

官

華

?.

בิ

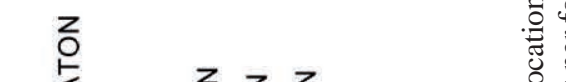

䓀

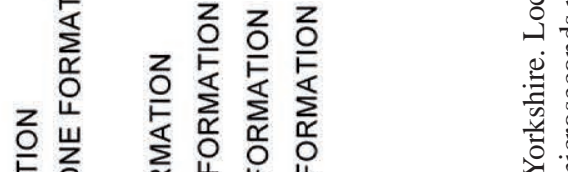

E

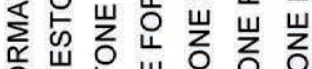

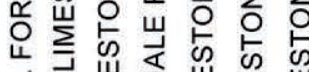

을쏘

이의

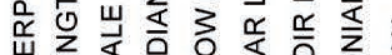

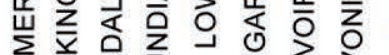

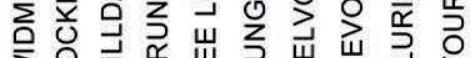

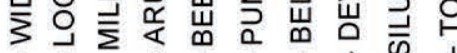

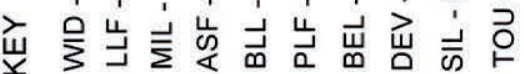
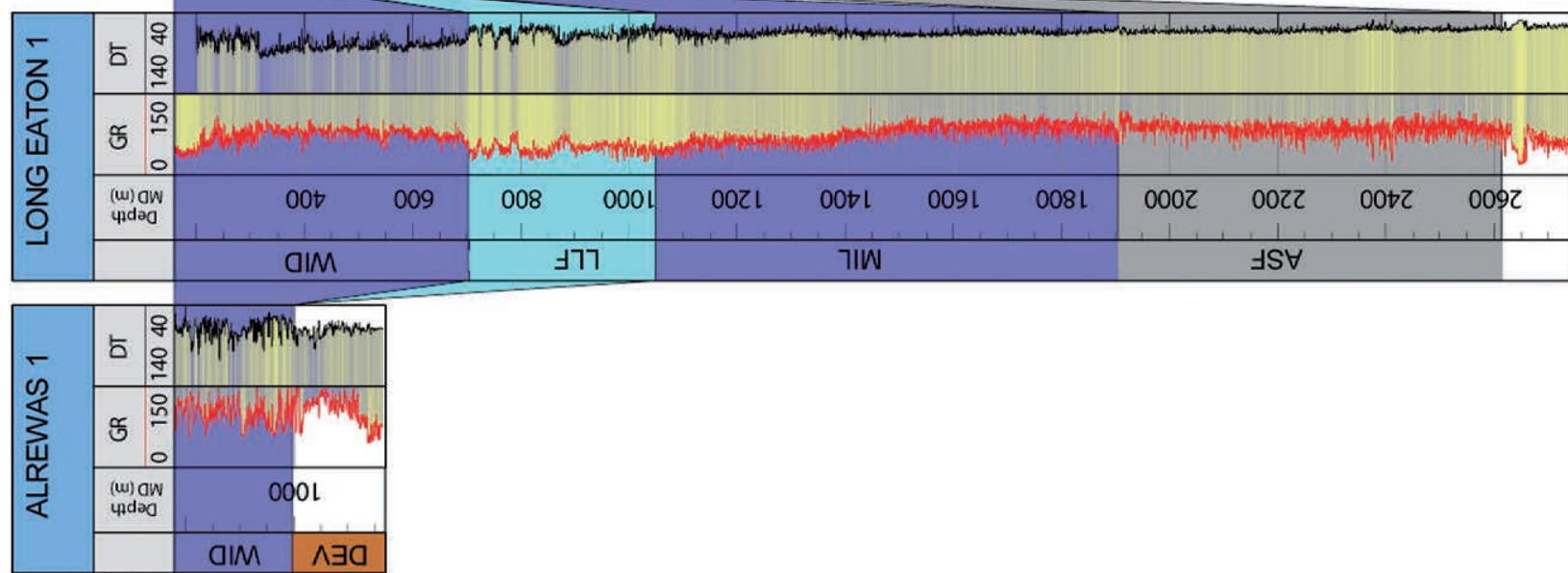

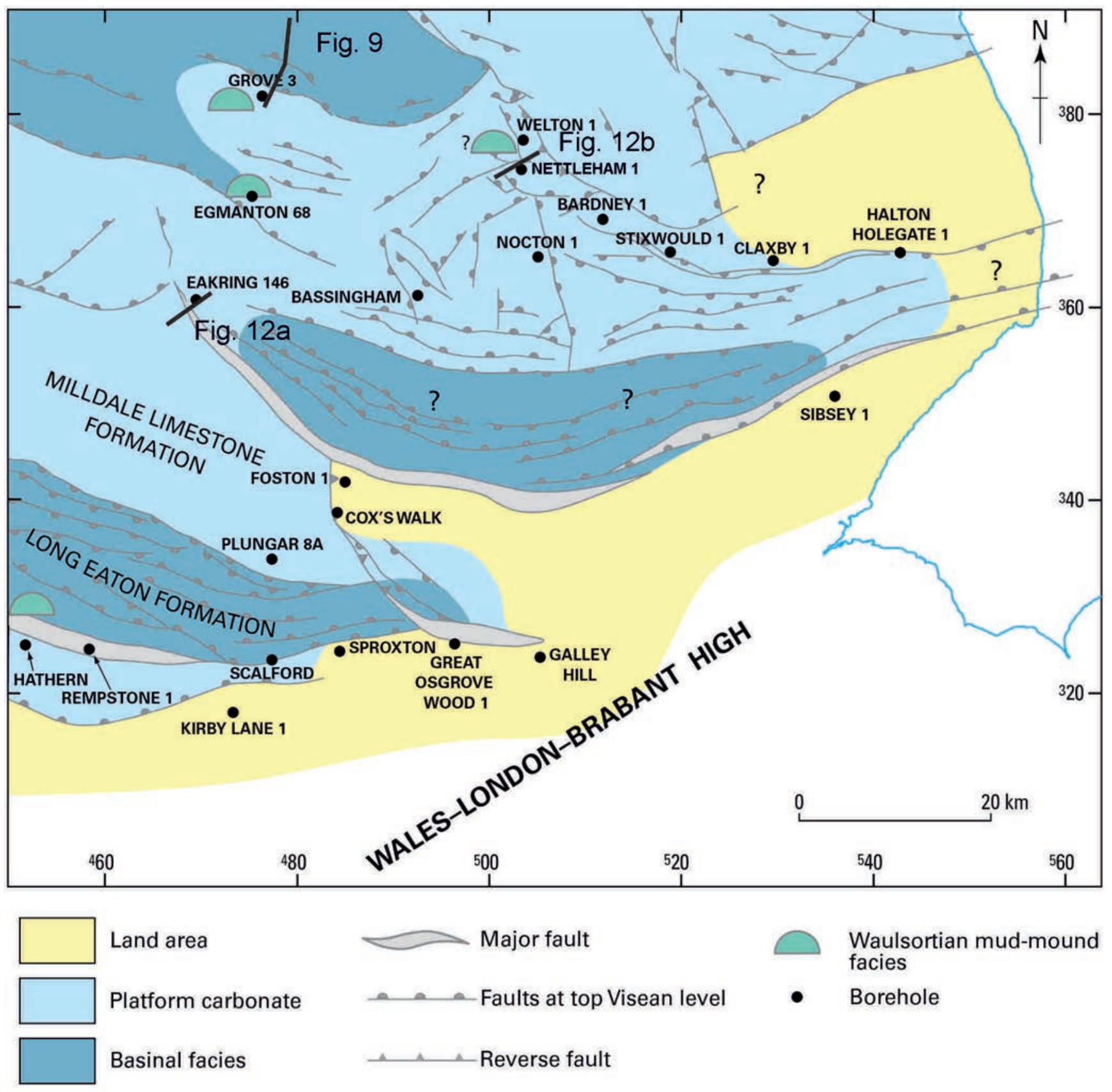

Land area

Platform carbonate

Basinal facies

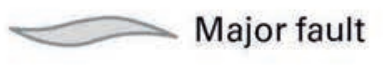

a Faults at top Visean level

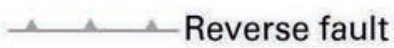

Fig. 11: Palaeogeographic map for basins of the East Midlands in Chadian time. Modified from Pharaoh et al. (2011) and Fraser \& Gawthorpe (1990). Key boreholes penetrating Mississippian strata, or the pre-Carboniferous basement, are shown. Occurrences of Waulsortianfacies mud-mounds are shown schematically. The location of 2D seismic reflection sections illustrated in the text is shown.

ian-Courceyan, Arundian and late Asbian time (Fig. 3). Intervening regressive system tracts in Chadian, early Asbian and Brigantian times, associated with sea-level lowstands, are reflected in emergence surfaces and palaeokarst development in the marginal platforms. In the Bowland Basin of Lancashire, basinal facies crop out, and contain a considerably reduced proportion of limestone (Waters et al. 2011).

During Tournaisian time, carbonate platforms in the equatorial belt worldwide e.g. in N America and China hosted 'Waulsortian' microbial mud-mounds (Muchez et al. 1991; Bridges et al. 1995). In the British Isles, spectacular examples crop out in the Isle of Man, but are under-represented in the drilling record in northern England because few boreholes here are sufficiently deep to penetrate Tournaisian strata (Fig. 10).

The Waulsortian 'mud-mounds' are of great interest in the present context because of their internal structure and diagenetic history. They comprise cores dominated by cri- 

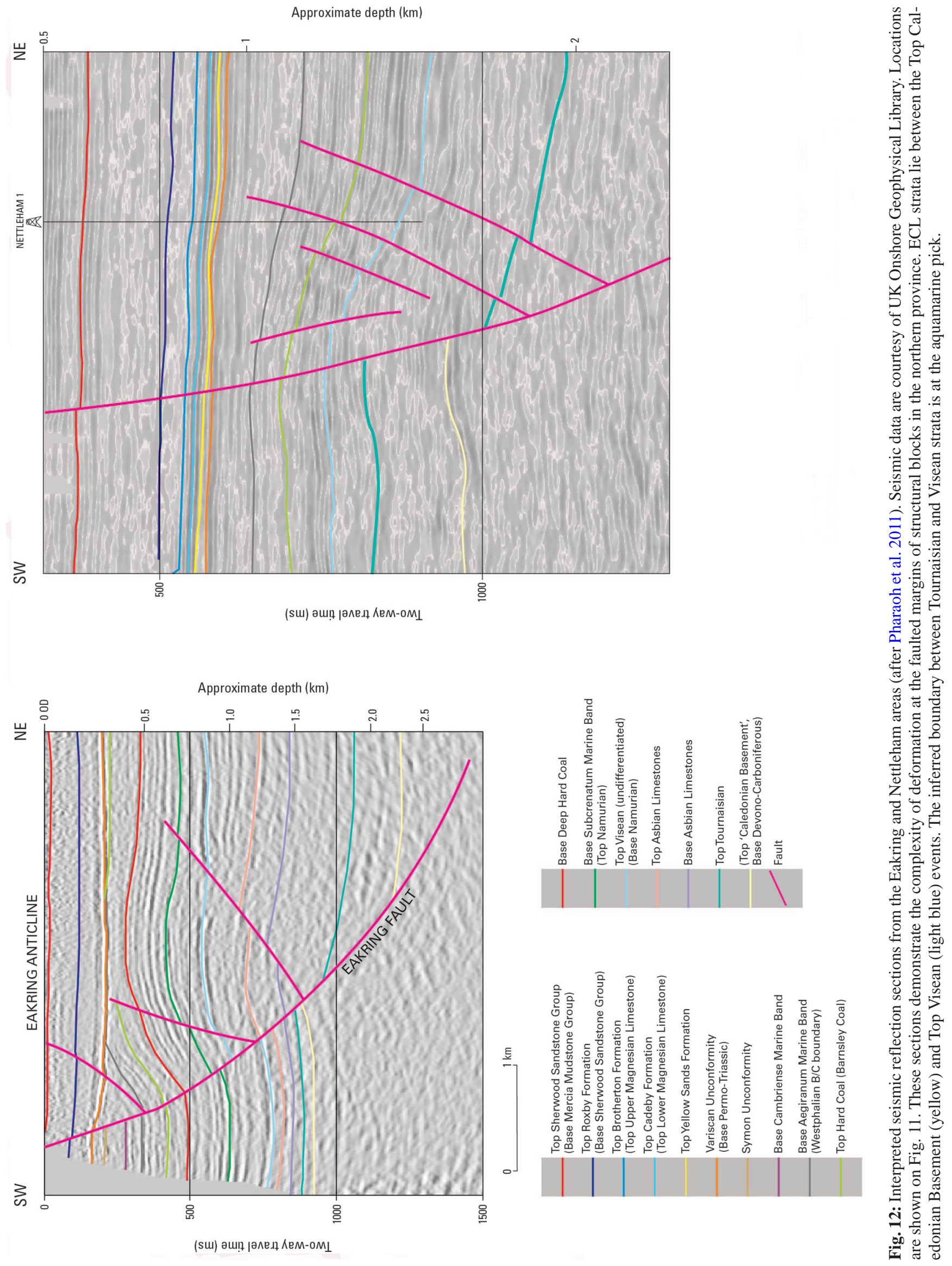
noids and bryozoa, which although incapable of providing a rigid organic framework like coral reefs, were nevertheless able to trap and stabilise micritic muds. The mud-mounds are localised at platform edges where major basin-bounding faults provide conduits for the venting of basinal fluids. Post-depositional exposure, dolomitisation and/or collapse of such structures can lead to the development of significant secondary porosity as seen in the Williston Basin of North Dakota and Saskatchewan where Waulsortian limestones form prolific hydrocarbon reservoirs (Kupecz et al. 1996; Miller \& Krause 2006). Such porous structures present an attractive target for geothermal exploration, e.g. around the margins of the Gainsborough Half-graben, where they would lie at depths between 2.5-4 km (Fig. 9). Although difficult to recognise on 2D seismic lines, recent developments in seismic technology (Hendry et al. 2021) may eventually allow their recognition in 3D seismic data. In Ireland, Waulsortian 'mud-mounds' are an important geothermal target due to their propensity for dolomitisation and karstification, particularly in strongly faulted zones (Blake et al. 2016; Vaz et al. 2018; Pracht et al. 2021, this issue) and are the source of most thermal springs. Some basins contain Tournaisian strata with significant evaporite-rich sections e.g. the Hathern Shelf (Fraser \& Gawthorpe 1990), and the NorthumberlandSolway Basin (Chadwick et al. 1995; Millward et al. 2019). The presence of evaporite minerals such as halite, gypsum and anhydrite enhances transmissivity, both by dissolution, creating locally significant porosity e.g. as in the Livian (= Holkerian) age Grande Brèche of Belgium (Fig. 3), and by the conversion of carbonate to dolomite during the migration of basinal brines.

Following diagenesis, the ECL of the northern province experienced a number of tectonic events which have increased permeability of the limestones. The completion log for the Nettleham 2 Borehole describes a karstified top of the ECL beneath Westphalian strata (Narayan et al. 2018, 2021). Namurian strata are absent over a wide area around Lincoln (Pharaoh et al. 2011). Karstified interfaces between the ECL and onlapping Namurian strata can be observed in outcrop in the Peak District (Ford 1989, 1996; Gutteridge 2002). Significant production of warm water from the oil reservoirs at Nettleham and Welton (Jon Gluyas pers. comm. 2019) is likely linked to such intersecting fracture systems. The polygonal framework of extensional faults described earlier was reactivated during Variscan inversion in latest Westphalian and Stephanian time (Pharaoh et al. 2011). The most significant reverse displacements were on pre-existing master faults orientated on NNW-SSE and NW-SE orientations, e.g. at Eakring to NNE of Nottingham, at Nocton and Nettleham near Lincoln (Figs. 11, 12). At the same time, a new generation of antithetic faults and associated damage zones was created, allowing the passage of hydrocarbons, brines and mineralising fluids through fracture networks, and creating a new generation of hypogene karst. At Eakring, the heat flow locally exceeds $70 \mathrm{~mW} / \mathrm{m}^{2}$, significantly in excess of the estimated background value (Gasiewicz et al. 2010). This has been attributed to regional eastward movement of groundwater from the Pennines (Bullard \& Niblett 1951;
Downing \& Howitt 1969), with upwelling at the EakringGlinton basement lineament (Chadwick \& Evans 2005; Pharaoh et al. 2011).

\section{Preliminary analysis of deep geothermal prospectivity in the ECL of the UK}

The preliminary analysis of ECL deep geothermal prospectivity is based on an analysis of Fig. 13, which shows calculated temperature at the top ECL surface, using regional average values for the geothermal gradient and mean annual surface temperature. This procedure is considered to provide more meaningful temperature values than individual bottomhole temperature, as the latter are known for being rather unreliable (subject to both measurement errors and correction method errors) which lead to a wide range of uncertainty when plotting individual temperatures on the map. The geothermal gradients are calculated from data in the UK Geothermal Catalogue (Rollin 1987), using corrected bottomhole temperatures in 209 wells penetrating ECL. For the north, the gradient is $28.5^{\circ} \mathrm{C} / \mathrm{km}$ and surface temperature is $10.1^{\circ} \mathrm{C}$; for the south, the gradient is $32.8^{\circ} \mathrm{C} / \mathrm{km}$ and surface temperature is $10.9^{\circ} \mathrm{C}$. Further details of the calculation procedure are presented by Jones et al. (2021). Temperature data are available across most of the area of interest. They are sparse near ECL outcrop (e.g. the Peak District) and in under-explored areas such as the Bowland Basin. They tend to cluster in well explored areas, such as the East Midlands Platform in the vicinity of Lincoln (Narayan et al. 2021).

It is possible to take a hierarchical approach to the analysis of the factors affecting the deep geothermal prospectivity of ECL. In order of scale and area of impact, these controls are as follows:

(1) First order Depositional Control creates major provincial variation (on a scale of $1000-100 \mathrm{~km}$ ), and is driven by lithospheric and global eustatic scale processes. Thus, areas of non-deposition of ECL, in particular the WABM, deep water, mud-dominated basins such as the Bowland, Gainsborough and Widmerpool basins; and basins with largely clastic Yoredale facies in the north, are rejected from the analysis. Regional uplift and/or sea-level fall associated with glaciation may cause province-wide uplift and emergence, karstification and pedogenesis.

(2) Second order Tectonic Control (on a scale of 100$10 \mathrm{~km}$ ) affects the post-depositional regional disposition of the ECL, and varies between the two provinces, still with a significant lithospheric component. Fig. 13 clearly shows that in the northern province, the ECL are disposed on either flank of the north-south trending Pennine Axis. The latter is reflected in the outcrop of ECL within the Peak District. On the western side, the ECL are rapidly taken deeper by subsidence following Permo-Triassic extension on the flank of the Irish Sea Basin, up to $5000 \mathrm{~m}$ deep in the Cheshire Basin. On the eastern flank, the gradient down towards the southern North Sea Basin is less steep, and the ECL are at a maximum depth of $3000 \mathrm{~m}$ at the coast in east Yorkshire. A further com- 

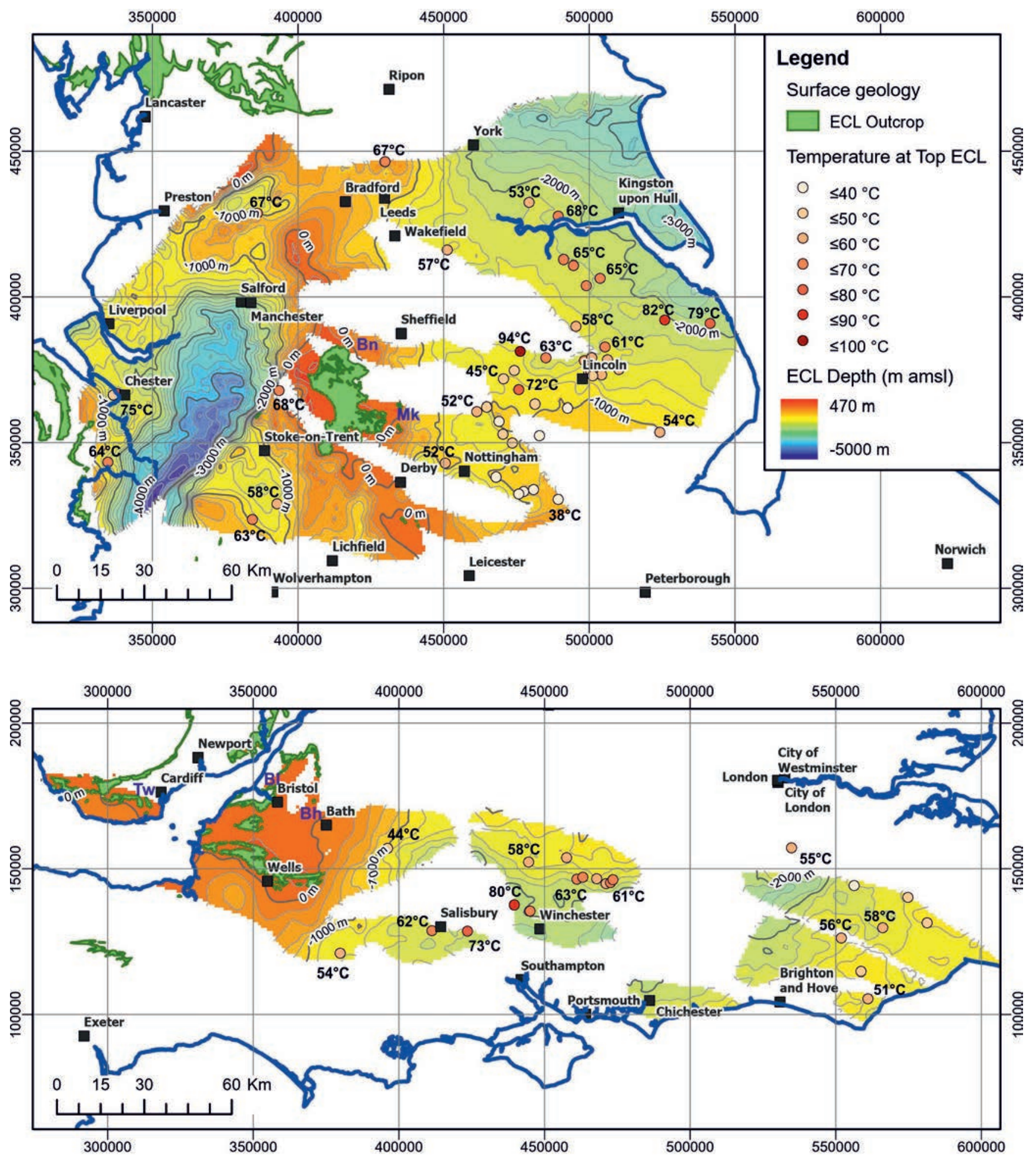

Fig. 13: Calculated temperature at the top of the ECL plotted on a map of depth to ECL (in metres, relative to mean sea-level) in southern Britain. See text for detail of the calculation. Outcrop of ECL highlighted in solid green colour.

ponent of uplift occurred on the axis in Cenozoic time. In the southern province, the dominant tectonic controls are Variscan thrusting and post-Variscan extension, which dissected the Mississippian Shelf into a number of isolated minibasins (Fig. 13).
(3) Third order Basin Morphology affects the disposition of tectonic elements, such as platforms, shelves and ramps within individual basins, resulting in significant local (10-1 km scale) variations in elevation e.g. as seen on the margins of the Gainsborough Half-graben (Fig. 9). On this 
scale, control from pre-depositional elements in the crust, such as zones of structural heterogeneity, shear-zones and granite plutons, becomes significant.

(4) Fourth order Carbonate Facies are controlled by the basin morphology and subsidence rate (depositional slope, orientation, exposure) established by the above controls, and may have a significant impact on porosity and permeability within carbonate sequences.

(5) Fifth order effects such as Faulting, Evaporite Dissolution, Dolomitisation and Mineralisation occur on the outcrop (1000-1 m) scale, but are particularly associated with basin-bounding fault structures which allow migration of basinal brines and the formation of hypogene karst.

(6) Sixth order effects such as Fracturing and Dissolution occur on the scale of outcrop to hand specimen (1-0.1 m).

Further work needs to be done to assess all the uncertainties and risks associated with exploration and exploitation, and is the subject of a play-fairway analysis currently in progress at BGS (Jones et al. 2021): depth of aquifer; seal integrity; thermal conductivity and thickness of cover (thermal blanket); reservoir properties; dolomitisation; and faulting/fracturing etc all require more detailed appraisal, possibly using innovative geophysical techniques and technology (Hendry et al. 2021). On the scale of the individual prospect, the uncertainties include the mode of carbonate deposition, particularly depth of water and angle of depositional slope, which are tectonically controlled; the history of synsedimentary exposure, erosion and palaeokarst development, strongly influenced by sea-level change; by the diagenetic history and subsequent basin evolution; deformation and fracturing during Variscan basin inversion; and the post-Carboniferous history of subsidence, uplift and karstification. Specific locations of interest discussed in the following text are shown in Fig. 14.

The northern province comprises a number of discrete basins, each with its unique pattern of subsidence, carbonate deposition and inversion, although broad comparisons on their evolution can be drawn (Fraser \& Gawthorpe 1990). The most prospective areas are presently considered to be carbonate platforms and their margins buried at depths between 2 and $4 \mathrm{~km}$ (coloured light blue). These areas underlie a number of cities within the 'Northern Powerhouse', such as Liverpool, Manchester, Blackburn, Leeds and Wakefield and extending as far north as York (Fig. 14). The major conurbations of East Lancashire (Oldham, Burnley) and SW Yorkshire (Bradford, Halifax, Huddersfield) lie not far from ECL outcrop, in the vicinity of the Pennine inversion axis, and thus at a comparatively high structural level. The scant bottomhole temperature data in this region are compatible with the use of ECL as a source of water in urban district heating schemes. Concealed ECL also lie at relatively shallow depth along the Hathern Shelf between Stoke and Derby (Fig. 13), beneath the Peak District, and the Holme High between Manchester and Leeds. Moving away from the ECL outcrop, seal integrity provided by the blanket of mudstones in overlying Namurian and Westphalian sequences is expected to increase, as demonstrated by the hydrocarbon systems in the province. It is likely that the highest bottomhole temperatures will be attained in the Cheshire Basin, where the ECL is most deeply buried (between Chester and Stokeon-Trent on Fig. 13). The floor of the basin was strongly eroded prior to deposition of Permian strata, and the disposition of ECL and overlying seals is poorly known, and therefore a major targeting risk. A very limited number of released boreholes penetrate the deepest part of the basin.

Moving eastward, the increasing thickness of cover provided by younger Carboniferous, Permian and Mesozoic strata means that the Market Weighton Platform as far north as York, the Humber Platform and the offshore extension onto the Hewett Shelf, offer prospects in the vicinity of Kingston upon Hull (Fig. 13). A borehole drilled at Cleethorpes (Fig. 1), near Grimsby during the previous investigation of the low enthalpy resource in the 1980's, encountered a temperature of $64{ }^{\circ} \mathrm{C}$ in basal Permian Yellow Sands at $1860 \mathrm{~m}$ depth (Downing \& Gray 1986). The margin of the Hewett Shelf in North Norfolk (Hickling) and Lincolnshire might offer greater geothermal prospectivity if accessed by deviated wells drilled from onshore, but a significant market is presently lacking.

The margins of the deepwater basins of the East Midlands and northern England offer prospects with lower targeting risks. Here a detailed coverage of relatively good quality seismic reflection data enables potential deep geothermal prospects to be defined e.g. on the margins of the Gainsborough Half-graben near Doncaster and Worksop in the 2.5 to $4 \mathrm{~km}$ depth range, and to the east, in the Lincoln district (Fig. 14). Numerous boreholes drilled into the largely Westphalian reservoirs of the many oilfields in the area (Fig. 13) yield bottomhole temperatures exceeding $50^{\circ} \mathrm{C}$. Namurian strata are absent here (Pharaoh et al. 2011) and the mudrich Westphalian succession provides the regional seal. Locally, as at Eakring and Egmanton, enhanced prospectivity may result from patterns of deep hydraulic flow within individual basins. In the deepwater basins themselves, e.g. the Widmerpool and Edale Half-graben, and in the Bowland Basin, the reduced content and thickness of limestone and strong Variscan inversion significantly reduce the prospectivity. The same is true in the Northumberland-Solway Basin (of Northumberland and North Cumbria) where the early Carboniferous sequence is dominated by clastic strata of 'Yoredale Facies' in which limestones are sparse, thin or absent. Even here, the presence of thick dissolution-prone evaporite sequences within ECL age-equivalent strata may encourage geothermal exploration. Basins within the WABM (coloured light green) are considered to be too shallow to be prospective for Deep Geothermal, except in the south (South Wales, North Somerset and Kent coalfields) where thicker sequences of limestone are buried to greater depth. Temperatures recorded by boreholes in the East Kent Coalfield are low and may be unduly influenced by the presence of adjacent flooded mine workings. The absence of a regional seal/thermal blanket is also a likely problem in these shallow areas.

Greatest uncertainty (but possibly good potential) lies in the concealed basins south of the Variscan Front. The stratigraphic and structural position of ECL in the southern prov- 


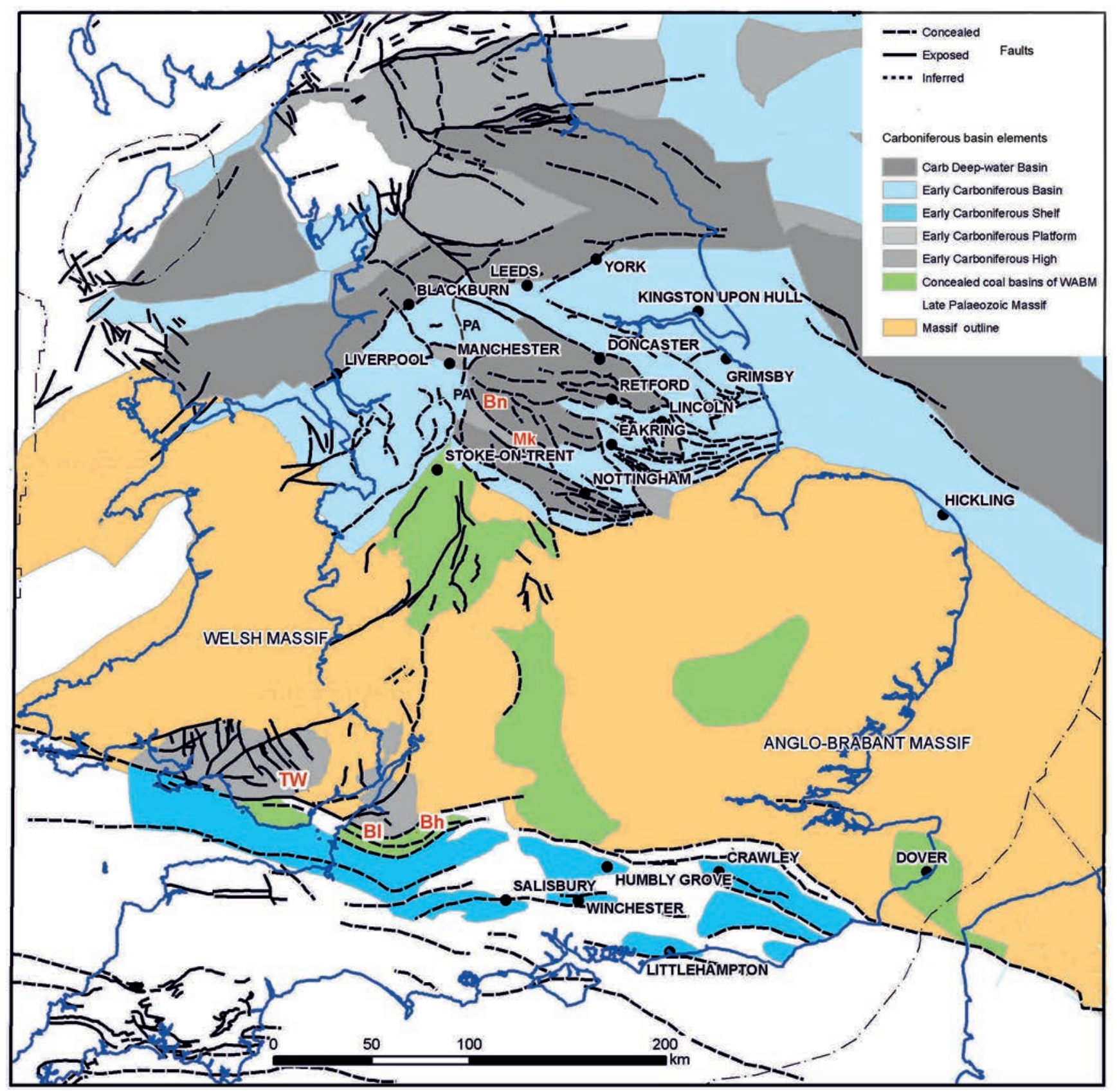

Fig. 14: Preliminary map of Deep Geothermal Prospectivity within ECL in the southern and central UK. Areas of interest and discussed in the text are indicated. Prospective areas, light blue; Non-prospective areas: Green, shallow coalfield basins on WABM; light grey, ECL at outcrop and on shallow buried platforms and highs; dark grey, deep basinal facies deficient in ECL. Key to thermal springs: Bh - Bath; Bl - Bristol; Bn - Buxton; Mk - Matlock; TW - Taff's Well.

ince is comparable to those of the Hainaut Basin in Belgium, and stratigraphic equivalents in northern France. Like them, they occupy the Rhenohercynian shelf extending along the southern margin of the WABM, forming the original continental margin of the Laurussia Palaeocontinent, with the Rheic Ocean lying to south. The subsurface mapping in progress by BGS (Jones et al. 2021) reveals that the original components of this shelf have been significantly dislocated by Variscan thrusting, as part of the Rhenohercynian Exter- nide Zone. As a consequence, the ECL have become compartmentalised into a number of relatively small subcrop patches ('minibasins'), and deeply eroded, so that Visean strata are largely removed. Nevertheless, the local preservation of a few hundred metres of Tournaisian strata, possibly containing enhanced porosity from the dissolution of original evaporites (as in the Hainaut Basin) at depths up to $3000 \mathrm{~m}$; the demonstration of widespread palaeokarst surfaces, of both intra-Carboniferous and late Triassic age; and 
the presence of working geothermal systems, at Bath and Humbly Grove, all provide encouragement to further exploration. The area around Salisbury and Winchester (Fig. 14) may offer a potential geothermal resource at a depth of 2.5 to $3 \mathrm{~km}$ with temperatures approaching $70^{\circ} \mathrm{C}$. Fig. 13 also includes some temperature values from the underlying Devonian strata, e.g. in the Southampton district, which augment the ECL data. As noted above, the Devonian strata themselves are unlikely to be prospective. Further potential may exist near Crawley and Littlehampton, on the margins of the Weald Basin (Fig. 14). The nature of potential regional seals needs further investigation, as the Variscan basement is overstepped by a variety of clastic to mudstone formations, ranging in age from Permian (in the SW) to late Triassic and or early Jurassic (in the north and east).

\section{Conclusions}

Early Carboniferous limestones were deposited in different environments on either flank of the Wales-Anglo-Brabant landmass. In the southern province, Mississippian strata were deposited on a shelf which stretched along the margin of the Laurussia Palaeocontinent, from Ireland to Germany, and can be correlated with the Hainaut Basin of Belgium. The stratigraphy appears to show limited variation across the province. The ECL subcrop occupies a series of discrete minibasins which were formed by Variscan thrusting and post-Variscan erosion. In the northern province, local tectonic controls combine with glacio-eustatic sea-level variation, to generate complex depositional environments on carbonate ramps, with significant and rapid stratigraphic variation. A complex mosaic of small basins, mostly comprising asymmetrical tilt-blocks, overlies a heterogeneously deformed pre-Carboniferous basement. These basins link via the Hewett Shelf across the southern North Sea to comparable structures in the Campine Basin of Belgium and The Netherlands. In northern England, the presence of graniteunderpinned blocks at crop, and basins filled with Yoredale facies rather than ECL, significantly reduces prospectivity.

The factors affecting deep geothermal prospectivity can be ranked in hierarchical order, ranging from the provincial $(1000 \mathrm{~km})$ down to outcrop $(1 \mathrm{~m})$ scale. These reflect the operation of processes working on lithospheric, crustal, basinal and sub-basinal scales. In both ECL provinces, the presence of palaeokarst systems, formed at times of uplift and erosion, and the dissolution of evaporite minerals, significantly enhance permeability. At present, drilling evidence is insufficient to confirm the contribution of Waulsortian facies to improved porosity, but the presence of such structures at the margins of deepwater basins in all surrounding countries certainly gives grounds for optimism. The hunt for such drilling targets will be considerably facilitated by the acquisition of wide and multi-azimuth 3D seismic data. Linkage of palaeokarst features by fracture systems and fault damage zones, is crucial to the development of enhanced deep thermal circulation systems. Where transmissive ECL lie at depths of $2 \mathrm{~km}$ or more, and are overlain by a regional seal/ thermal blanket, they have the potential to provide a deep geothermal resource applicable to a variety of markets.

The first oil discovery in Britain was made in the ECL by the Hardstoft No. 1 Borehole in 1919 (Craig et al. 2014). So, it would be wholly appropriate if, one century on, the ECL were to be the first deep geothermal resource to contribute significantly to the decarbonisation of heating in the UK.

\section{Acknowledgements}

This paper is a published product of research by the Cooling and Heating Team of the Decarbonisation and Resource Management Directorate, British Geological Survey. Publication is with the approval of the Executive Director, British Geological Survey. The paper is available by Open Access thanks to financial support from the Interreg NWE Programme for the Roll-out of Deep Geothermal Energy in North-West Europe (DGE-ROLLOUT) Project (www. nweurope.eu/DGE-Rollout). Seismic data were provided by UK Onshore Geophysical Library (UKOGL). Liz Scott drafted many of the diagrams.Vanessa Banks is thanked for the BGS internal review; external reviews by David Lagrou and Michiel Dusar are gratefully acknowledged.

\section{References}

Abesser, C., \& Smedley, P. (2008). Baseline groundwater chemistry of aquifers in England and Wales: The Carboniferous Limestone aquifer of the Derbyshire Dome. London: British Geological Survey Open Report OP/08/028.

Abesser, C., Shand, P., \& Ingram, J. (2005). The Carboniferous limestone of Northern England. Baseline Report Series 22. British Geological Survey Commissioned Report, CR/05/076N.

Andrews, I. J. (2013). The Carboniferous Bowland Shale gas study: Geology and resource estimation. London: British Geological Survey for Department of Energy and Climate Change.

Atkins (2013). Deep Geothermal review Study Final Report. Department of Energy and Climate Change (DECC). https:// assets.publishing.service.gov.uk/government/uploads/system/ uploads/attachment_data/file/251943/Deep_Geothermal_Review_Study_Final_Report_Final.pdf

Berckmans, A., \& Vandenberghe, N. (1998). Use and potential of geothermal energy in Belgium. Geothermics, 27(2), 235-242. https://doi.org/10.1016/S0375-6505(97)10010-4

Blake, S., Henry, T., Muller, M. R., Jones, A. G., Moore, J. P., Murray, J., . . . Rath, V. (2016). Understanding hydrothermal circulation patterns at a low-enthalpy thermal spring using audio-magnetotelluric data: A case study from Ireland. Journal of Applied Geophysics, 132, 1-16. https://doi.org/10.1016/j.jappgeo.2016.06.007

Bless, M. J. M., Bouckaert, J., Bouzet, P., Conil, R., Cornet, P., Fairon-Demaret, M., . . . Wolf, M. (1976). Dinantian rocks in the subsurface North of the Brabant and Ardenno-Rhenish massifs in Belgium, the Netherlands and the Federal Republic of Germany. Mededelingen Rijks Geologische Dienst, 27(3), 81195.

Booth, M. G., Underhill, J. R., Gardiner, A., \& McLean, D. (2020). Sedimentary and tectonic controls on Lower Carboniferous (Visean) mixed carbonate-siliciclastic deposition in NE En- 
gland and the Southern North Sea: Implications for reservoir architecture. Petroleum Geoscience, 26(2), 204-231. https:// doi.org/10.1144/petgeo2019-101

Bos, S., \& Laenen, B. (2017). Development of the first deep geothermal doublet in the Campine Basin of Belgium. European Geologist, 43, 16-21.

Bott, M. H. P. (1967). Geophysical investigations of the northern Pennine basement rocks. Proceedings of the Yorkshire Geological Society, 36(2), 139-168. https://doi.org/10.1144/ pygs.36.2.139

Bott, M. H. P. (1987). Subsidence mechanisms of Carboniferous Basins in Northern England. In J. Miller, A. E. Adams, \& V. P. Wright (Eds.), European Dinantian environments (pp. 21-32). New York: John Wiley \& Sons.

Bridges, P. H., Gutteridge, P., \& Pickard, N. A. H. (1995). The environmental setting of Early Carboniferous mud-mounds. In C. L. V. Monty, D. W. J. Bosence, P. H. Bridges, \& B. R. Pratt (Eds.), Carbonate mud-mounds: their origin and evolution. International Association of Sedimentologists Special Publication, 23, 171-190. https://doi.org/10.1002/9781444304114.ch6

Broothaers, M., Lagrou, D., Laenen, B., Harcouët-Menou, V., \& Vos, D. (2021). Deep geothermal energy in the Lower Carboniferous carbonates of the Campine Basin, northern Belgium: An overview from the 1950's to 2020. [this issue]. Zeitschrift der Deutschen Gesellschaft für Geowissenschaften, 172(3), 211225. https://doi.org/10.1127/zdgg/2021/0285

Bullard, E. C., \& Niblett, E. R. (1951). Terrestrial heat flow in England. Geophysical Journal International, 6(s4), 222-238. https://doi.org/10.1111/j.1365-246X.1951.tb03007.x

Burgess, W. G., Burley, A. J., Downing, R. A., Edmunds, W. M., \& Price, M. J. (1981). The Marchwood Borehole - A preliminary assessment of the resource. Investigations of the Geothermal Potential of the UK. Institute of Geological Sciences.

Busby, J. (2014). Geothermal energy in sedimentary basins in the UK. Hydrogeology Journal, 22(1), 129-141. https://doi. org/10.1007/s10040-013-1054-4

Chadwick, R. A., \& Evans, D. J. (2005). Fault and structure atlas. Special Publication, British Geological Survey.

Chadwick, R. A., Holliday, D. W., Holloway, S., \& Hulbert, A. G. (1995). The Northumberland-Solway basin and adjacent areas. Subsurface Memoir (90 pp.). Keyworth: British Geological Survey.

Cohen, K. M., Finney, S., \& Gibbard, P. L. (2012). International Chronostratigraphic Chart. International Commission on Stratigraphy. www.stratigraphy.org

Craig, J., Gluyas, J. G., Laing, C., \& Schofield, P. (2014). Hardstoft - Britain's first oil field. Oil Industry History, 14, 97-116.

Darling, W. G. (2019). Thermal groundwaters of the UK: Geochemical indications of flow, vulnerability and possible threat to the shallow hydrosphere. Quarterly Journal of Engineering Geology and Hydrogeology, 52(4), 557-562. https://doi. org/10.1144/qjegh2018-199

Davies, S. J., \& Fielding, C. R. (2008). The record of Carboniferous sea-level change in low-latitude sedimentary successions from Britain and Ireland during the onset of the late Paleozoic ice age. In C. R. Fielding, T. D. Frank, \& J. L. Isbell (Eds.), Geological Society of America, Special Papers: Vol. 441. Resolving the Late Paleozoic ice age in time and space (pp. 187-204). https://doi.org/10.1130/2008.2441(13)

Delmer, A., Rorive, A., \& Stenmans, V. (1996). Dix ans de géothermie en Hainaut. Bulletin de la Société Belge de Géologie, 105, 77-85.
Downing, R. A., \& Gray, R. A. (Eds.) (1986). Geothermal energy - The potential in the United Kingdom (180 pp.). London: British Geological Survey.

Downing, R. A., \& Howitt, F. (1969). Saline groundwaters in the Carboniferous rocks of the English East Midlands. Bulletin Geological Survey of Great Britain, 27, 289-307.

Dusar, M., \& Lagrou, D. (2008). Paleokarst-enhanced reservoir for geothermics and gas storage in Carboniferous limestone (Campine Basin, NW European Carboniferous Basin). In I. D. Sasowsky, C. T. Feazel, J. E. Mylroie, A. N. Palmer, \& M. V. Palmer (Eds.), Karst from Recent to reservoirs, June 7-11. Rapid City, South Dakota. Karst Waters Institute Special Publication, 14, 43-51.

Edmunds, W. M. (1986). Geochemistry of geothermal waters in the UK. In R. A. Downing, \& R. A. Gray (Eds.), Geothermal energy - the potential in the United Kingdom (pp. 111-122). London: British Geological Survey.

Faulkner, T. J., Wright, V. P., Peeters, C., \& Garvie, L. (1990). Cryptic exposure horizons in the Carboniferous Limestone of Portishead, Avon. Geological Journal, 25(1), 1-17. https://doi. org/10.1002/gj.3350250102

Ford, T. D. (1989). Paleokarst of Britain. In P. Bosák, D. C. Ford, J. Głazek, \& I. Horáček, I. (Eds), Palaeokarst: A systematic and regional review. Developments in Earth Surface Processes (pp. 51-70). Amsterdam: Elsevier. https://doi.org/10.1016/B978-0444-98874-4.50012-4

Ford, T. D. (1996). The Castleton area, Derbyshire. Geologists' Association Guide, 56, 1-93.

Fraser, A. J., \& Gawthorpe, R. L. (1990). Tectono-stratigraphic development and hydrocarbon habitat of the Carboniferous in northern England. In R. F. P. Hardman \& J. Brooks (Eds.), Tectonic events responsible for Britain's oil and gas reserves. Special Publication - Geological Society of London, 55, 49-86. https://doi.org/10.1144/GSL.SP.1990.055.01.03

Gallois, R. W. (2007). The formation of the hot springs at Bath Spa, U.K. Geological Magazine, 144(4), 741-747. https://doi. org/10.1017/S0016756807003482

Gasiewicz, A., Bos, C., Czapowski, G., Evans, D., Górecki, W., Hajto, M., . . . Wong, T. E. (2010). Applied geology. In J. H. Doornenbal \& A. G. Stevenson (Eds.), Petroleum Geological Atlas of the Southern Permian Basin (pp. 283-299). Houten: EAGE.

Gluyas, J. G., De-Paola, N., Imber, J., Jezierski, T. M., Jones, R. R., Jordan, P., . . . Moors, A. (2020). The Humbly Grove, Herriard and Hester's Copse fields, UK Onshore. In J. G. Gluyas \& G. Goffey (Eds.), Geological Society, London, Memoirs: Vol. 52. United Kingdom oil and gas fields (pp. 74-81).

Gradstein, F. M., Ogg, J. G., Schmitz, M., \& Ogg, G. (Eds.). (2012). The Geologic Time Scale 2012. Boston: Elsevier; https://doi. org/10.1016/B978-0-444-59425-9.00004-4

Gutteridge, P. (2002). Trip 1: Late Dinantian evolution of the northern margin of the Derbyshire Carbonate platform, Castleton. Field Guide Volume, Hydrocarbon Resources of the Carboniferous, Southern North Sea and surrounding onshore areas (pp. 1-46). Yorkshire Geological Society.

Hendry, J., Burgess, P., Hunt, D., Janson, X., \& Zampetti, V. (2021). Seismic characterisation of carbonate platforms and reservoirs: An introduction and review. Special Publication - Geological Society of London, 509, SP509-2021-51. https://doi. org/10.1144/SP509-2021-51

Holliday, D. W. (1986). Devonian and Carboniferous basins. In R. A. Downing \& R. A. Gray (Eds.), Geothermal energy - The potential in the United Kingdom (pp. 84-110). London: HMSO. 
IGas Energy plc (2019). Full year results 2018. Igasplc.com/media/39950/full-year-results-2018.pdf

Jones, D. J. R., Pharaoh, T. C., Randles, T., Kearsey, T., \& Newell, A. (2021). Initial assessment of the deep geothermal potential of the UK Carboniferous Basins. British Geological Survey Internal Report, IR/21/007 (32 pp.).

Juerges, A., Hollis, C. E., Marshall, J., \& Crowley, S. (2016). The control of basin evolution on patterns of sedimentation and diagenesis: An example from the Mississippian Great Orme, North Wales. Journal of the Geological Society, 173(3), 438-456. https://doi.org/10.1144/jgs2014-149

Kearsey, T. I., Millward, D., Ellen, R., Whitbread, K., \& Monaghan, A. A. (2019). Revised stratigraphic framework of pre-Westphalian Carboniferous petroleum system elements from the Outer Moray Firth to the Silverpit Basin, North Sea, UK. Special Publication - Geological Society of London, 471(1), 91-113. https://doi.org/10.1144/SP471.11

Kirby, G. A., Baily, H. E., Chadwick, R. A., Evans, D. J., Holliday, D. W., Holloway, S., . . . Birch, B. (2000). The structure and evolution of the Craven Basin and adjacent areas: Subsurface memoir (130 pp.). London: British Geological Survey.

Kirkham, A. (2005). Thrombolitic-Ortonella reefs and their bacterial diagenesis, Upper Visean Clifton Down Limestone, Bristol area, SW England. Proceedings of the Geologists'Association, 116, 221-234.

Kombrink, H., Besly, B. M., Collinson, J. D., Den Hartog Jager, D. G., Drozdzewski, G., Dusar, M., ... Wrede, V. (2010). Carboniferous. In J. H. Doornenbal \& A. G. Stevenson (Eds.), Petroleum Geological Atlas of the Southern Permian Basin (pp. 8199). Houten: EAGE.

Kupecz, J. A., Arestad, J. F., \& Blott, J. E. (1996). Integrated study of Mississippian Lodgepole Waulsortian Mounds, Williston Basin, USA. Paper SEG-1996-0401, SEG Annual Meeting, 10-15 November 1996, Denver, Colorado.

Lagrou, D., \& Laenen, B. (2012). Introduction of new formal lithostratigraphic units for the Dinantian in the Campine Basin. Proceedings of the 4th International Geologica Belgica Meeting 2012. 11-14 September 2012, Brussels: 289.

Lagrou, D., \& Laenen, B. (2014). https://ncs.naturalsciences.be/ carboniferous/dinantian-campine-basin

Laurent, A., Beccaletto, L., Averbuch, O., Graveleau, F., Lacquement, F., Caritg, S., . . . Capar, L. (2021). Modelling the 3D geometry of the Dinantian carbonate geothermal reservoir in Northern France. [this issue]. Zeitschrift der Deutschen Gesellschaft für Geowissenschaften, 172(3), 293-305. https://doi. org/10.1127/zdgg/2021/0284

Licour, L. (2014). The geothermal reservoir of Hainaut: The result of thermal convection in a carbonate and sulfate aquifer. Geologica Belgica, 17, 75-81.

Lovegrove, J., Newell, A. J., Whiteside, D. I., \& Benton, M. J. (2021). Testing the relationship between marine transgression and evolving island palaeogeography using 3D GIS: An example from the Late Triassic of SW England. Journal of the Geological Society, 178(3), 1-19. https://doi.org/10.1144/jgs2020158

Manning, D. A. C., Younger, P. L., Smith, F. W., Jones, J. M., Dufton, D. J., \& Diskin, S. (2007). A deep geothermal exploration well at Eastgate, Weardale, UK: A novel exploration concept for low enthalpy resources. Journal of the Geological Society, 164(2), 371-382. https://doi.org/10.1144/0016-76492006-015

Menning, M., Alekseev, A., Chuvashov, B. I., Davydov, V. I., Devuyst, F.-X., Forke, H. C., . . . Work, D. M. (2006). Global time scale and regional stratigraphic reference scales of Central and West Europe, East Europe, Tethys, South China, and North America as used in the Devonian-Carboniferous-Permian Correlation Chart 2003 (DCP2003). Palaeogeography, Palaeoclimatology, Palaeoecology, 240(1-2), 318-372. https://doi. org/10.1016/j.palaeo.2006.03.058

Mijnlieff, H. F. (2020). Introduction to the geothermal play and reservoir geology of The Netherlands. Netherlands Journal of Geosciences, 99, e2. https://doi.org/10.1017/njg.2020.2

Miller, C., \& Krause, F. (2006). Waulsortian lithofacies of the Mississippian Souris Valley Beds (Lodgepole Formation), Williston Basin, Southeastern Saskatchewan, Canada. Saskatchewan Geological Society Special Publication, 19, 173-183.

Millward, D., Davies, S. J., Brand, P. J., Browne, M. A. E., Bennett, C. E., Kearsey, T. I., . . Marshall, J. E. A. (2019). Palaeogeography of tropical seasonal coastal wetlands in northern Britain during the early Mississippian Romer's Gap. Earth and Environmental Science Transactions of the Royal Society of Edinburgh, 109(1-2), 279-300. https://doi.org/10.1017/ S1755691018000737

Muchez, P., \& Peeters, C. (1987). The occurrence of a cryptalgal reef structure in the Upper Visean of the Visé area (the Richelle quarries). Annales de la Société Géologique de Belgique, 109, 573-577.

Muchez, P., Viaene, W., Bouckaert, J., Conil, R., Dusar, M., Poty, E., .. . Vandenberghe, N. (1991). The occurrence of a microbial buildup at Poederlee (Campine Basin, Belgium): Biostratigraphy, sedimentology, early diagenesis and significance for early Warnantian paleogeography. Annales de la Société Géologique de Belgique, 113, 329-339.

Narayan, H. (2019). The geothermal potential of karstified Lower Carboniferous limestones in the UK. Ph.D. thesis, Durham University [unpublished].

Narayan, N.S., Adams, C.A., \& Gluyas, J.G. (2021). Karstified and fractured Lower Carboniferous (Mississippian) limestones of the UK - a cryptic geothermal reservoir. [this issue]. Zeitschrift der Deutschen Gesellschaft für Geowissenschaften, 172(3), 251-265. https://doi.org/10.1127/zdgg/2021/0288

Narayan, N., Gluyas, J., \& Adams, C. (2018). Is the UK in hot water? Geoscientist, 28(9), 10-15. https://doi.org/10.1144/ geosci2018-014

Newport, S. M., Jerrett, R. M., Taylor, K. G., Hough, E., \& Worden, R. H. (2018). Sedimentology and microfacies of a mud-rich slope succession: In the Carboniferous Bowland Basin, NW England (UK). Journal of the Geological Society, 175(2), 247262. https://doi.org/10.1144/jgs2017-036

Pharaoh, T. (2018). The Anglo-Brabant Massif: Persistent but enigmatic palaeo-relief at the heart of western Europe. In M. A. Woods, \& J. R. Lee (Eds.), The Geology of England. Proceedings of the Geologists' Association, 129(3), 278-328. https://www. sciencedirect.com/science/article/pii/S0016787818300294

Pharaoh, T., Vincent, C., Bentham, M., Hulbert, A. G., Waters, C. N., \& Smith, N. J. P. (2011). Structure and evolution of the East Midlands region of the Pennine Basin: Subsurface Memoir (144 pp.). London: British Geological Survey.

Poty, E. (2016). The Dinantian (Mississippian) succession of southern Belgium and surrounding areas: Stratigraphy improvement and inferred climate reconstruction. Geologica Belgica, 19(12), 177-200. https://doi.org/10.20341/gb.2016.014

Poty, E., Devuyst, F.-X., \& Hance, L. (2006). Upper Devonian and Mississippian foraminiferal and rugose coral zonation of Belgium and northern France: A tool for Eurasian correlations. Geological Magazine, 143(6), 829-857. https://doi.org/10.1017/ S0016756806002457 
Pracht, M., Rogers, R., \& McConnell, B. J. (2021). Mississippian (Dinantian) of Ireland and its geothermal potential. [this issue]. Zeitschrift der Deutschen Gesellschaft für Geowissenschaften, 172(3), 267-292. https://doi.org/10.1127/zdgg/2021/0280

Pullan, C. P., \& Butler, M. (2019). Palaeozoic gas potential in the Weald Basin of southern England. In A. A. Monaghan, J. R. Underhill, A. J. Hewett, \& J. E. A. Marshall (Eds.), Palaeozoic plays of NW Europe. Special Publication - Geological Society of London, 471, 333-364. https://doi.org/10.1144/SP471.1

Reijmer, J. J. G., ten Veen, J. H., Jaarsma, B., \& Boots, R. (2017). Seismic stratigraphy of Dinantian carbonates in the southern Netherlands and northern Belgium. Netherlands Journal of Geosciences, 96(4), 353-379. https://doi.org/10.1017/njg.2017.33

Rockel, W., Hoth, P., \& Seibt, P. (1997). Charakteristik und Aufschluss hydrogeothermaler Speicher. Geowissenschaften, 8, 244-252.

Rollin, K. E. (1987). Catalogue of geothermal data for the land area of the United Kingdom. $3^{\text {rd }}$ revision April 1987. Investigation of the geothermal potential of the UK. Keyworth: British Geological Survey.

Rorive, A., \& Licour, L. (2014). Géothermie profonde en Wallonie. In A. Dassargues \& K. Walraevens (Eds.), Watervoerende lagen \& grondwater in België - Aquifères \& eaux souterraines en Belgique (pp. 367-374). Gent: Academia Press.

Rorive, A., \& Licour, L. (2015). Nos ressources énergétiques souterraines: La géothermie de basse énergie en Wallonie. Revue E tijdschrift, 130(3).

Smith, N. J. P. (compiler) (1985). Map 1. Pre-Permian Geology of the United Kingdom (South). Keyworth: British Geological Survey.

Smith, N. J. P., Kirby, G. A., \& Pharaoh, T. C. (2005). Structure and evolution of the south-west Pennine Basin and adjacent area: subsurface memoir (129 pp.). Keyworth: British Geological Survey.

Tucker, M., Gallagher, J., Lemon, K., \& Leng, M. (2003). The Yoredale cycles of Northumbria: High-frequency clastic-carbonate sequences of the Mid-Carboniferous icehouse world. Northumbria Rocks, 18(26), 5-10.

van der Voet, E., Muchez, P., Laenen, B., Weltje, G. J., Lagrou, D., \& Swennen, R. (2020). Characterizing carbonate reservoir fracturing from borehole data - A case study of the Viséan in northern Belgium. Marine and Petroleum Geology, 111, 375-389. https://doi.org/10.1016/j.marpetgeo.2019.08.040

Van Hulten, F. F. N. (2012). Devono-Carboniferous carbonate platform systems of the Netherlands. Geologica Belgica, 15(4), 284-296.

Vaz, L., Lewis, D., O’Neill, N., \& Blake, S. (2018). Investigation of Irish Carboniferous palaeokarst for $\mathrm{CO}_{2}$. Geological Storage
\& Deep Geothermal Resource. Prepared for the Geological Survey of Ireland.

Walkden, G. (1987). Sedimentary and diagenetic styles in Late Dinantian Carbonates of Britain. In J. Miller, A. E. Adams, \& V. P. Wright (Eds.), European Dinantian environments (pp. 131156). New York: John Wiley \& Sons.

Walsh, P. T., Banks, V. J., Jones, P. F., Pound, M. J., \& Riding, J. B. (2018). A reassessment of the Brassington Formation (Miocene) of Derbyshire, UK and a review of related hypogene karst suffusion processes. Journal of the Geological Society, 175(3), 443-463. https://doi.org/10.1144/jgs2017-029

Waters, C. N., \& Davies, S. J. (2006). Carboniferous: extensional basins, advancing deltas and coal swamps. In P. J. Brenchley \& P. F. Rawson (Eds.), The geology of England and Wales (pp. 173-223). London: Geological Society. https://doi.org/10.1144/ GOEWP.9

Waters, C. N., Somerville, I. D., Jones, N. S., Cleal, C. J., Collinson, J. D., Waters, R. A., ... McLean, D. (2011). A revised correlation of Carboniferous rocks in the British Isles. (186 pp.). Geological Society, London, Special Report, 26. https:// doi.org/10.1144/SR26

Waters, C. N., Vane, C. H., Kemp, S. J., Haslam, R. B., Hough, E., \& Moss-Hayes, V. L. (2020). Lithological and chemostratigraphic discrimination of facies within the Bowland Shale Formation within the Craven and Edale basins, UK. Petroleum Geoscience, 26(2), 325-345. https://doi.org/10.1144/petgeo2018-039

Watson, S. M., Falcone, G. F., \& Westaway, R. (2020). Repurposing hydrocarbon wells for geothermal use in the UK: The onshore fields with the greatest potential. Energies, 13(14), 3541. https://doi.org/10.3390/en13143541

Whittaker, A., Holliday, D. W., \& Penn, I. E. (1985). Geophysical logs in British stratigraphy. (74 pp.). Geological Society, London, Special Report, 18.

Wright, V. P. (1986). Facies sequences on a carbonate ramp: The Carboniferous limestone of South Wales. Sedimentology, 33(2), 221-241. https://doi.org/10.1111/j.1365-3091.1986.tb00533.x

Wright, V. P. (1990). Equatorial aridity and climatic oscillations during the early Carboniferous, southern Britain. Journal of the Geological Society, 147(2), 359-363. https://doi.org/10.1144/ gsjgs.147.2.0359

Manuscript received: 26.02.2021

Revisions required: 12.04 .2021

Revised version received: 07.06.2021

Accepted for publication: 08.06.2021 